FORUM REVIEW ARTICLE

\title{
Anticancer thiosemicarbazones: chemical properties, interaction with iron metabolism, and resistance development
}

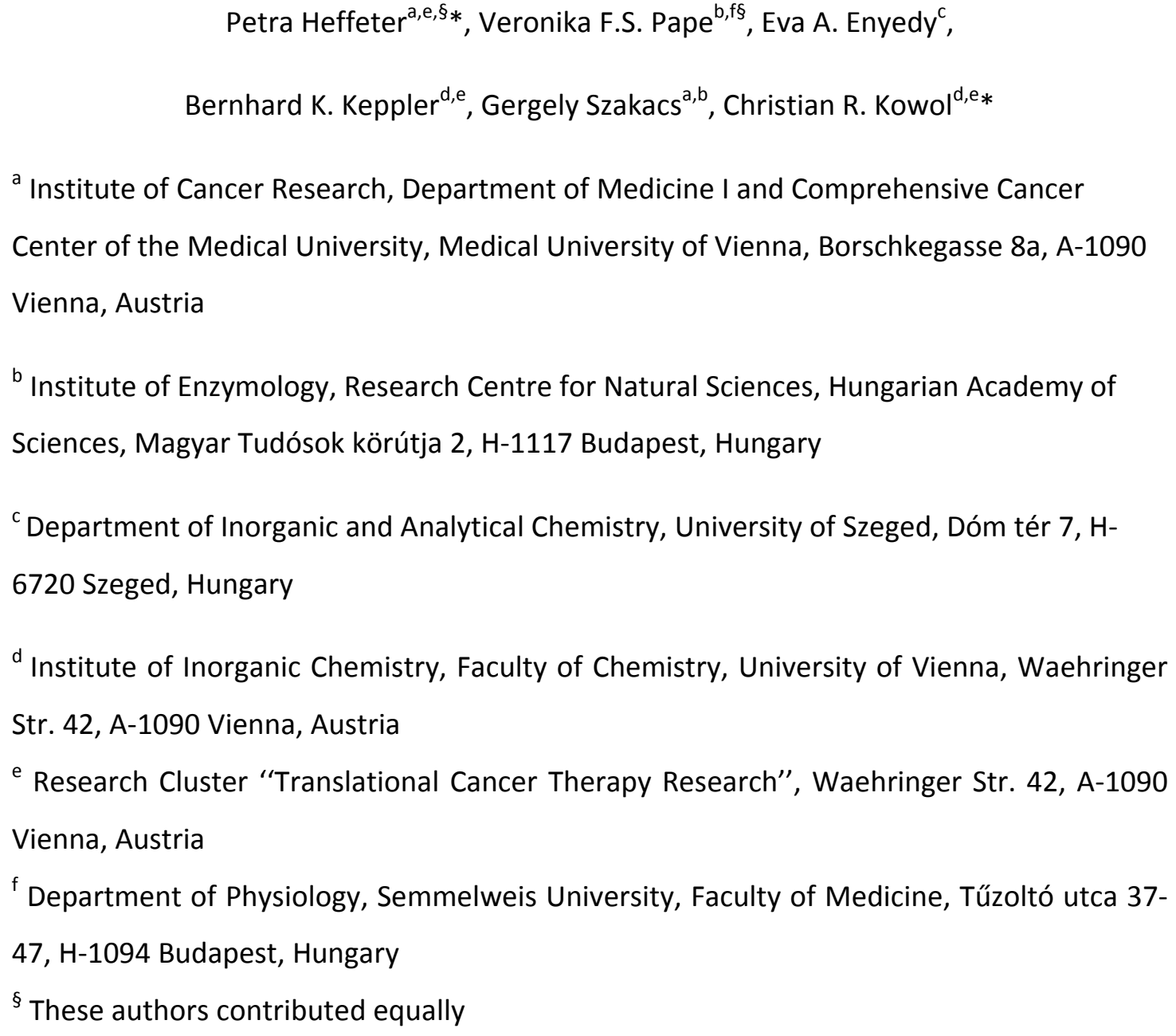

Authors for correspondence: Petra Heffeter, Institute of Cancer Research, Medical University of Vienna, Borschkeg. 8a, A-1090 Vienna, Austria. Phone: +43-1-40160-57594. Fax: +43-1-40160-957555. E-mail: petra.heffeter@meduniwien.ac.at

Christian R. Kowol, Institute of Inorganic Chemistry, University of Vienna, Waehringer Str. 42, A-1090 Vienna, Austria. Phone: +43-1-4277-52609. Fax: +43-1-4277-52680. E-mail: christian.kowol@univie.ac.at. 
Page 2 of 63

Abbreviated title: Thiosemicarbazones and iron metabolism

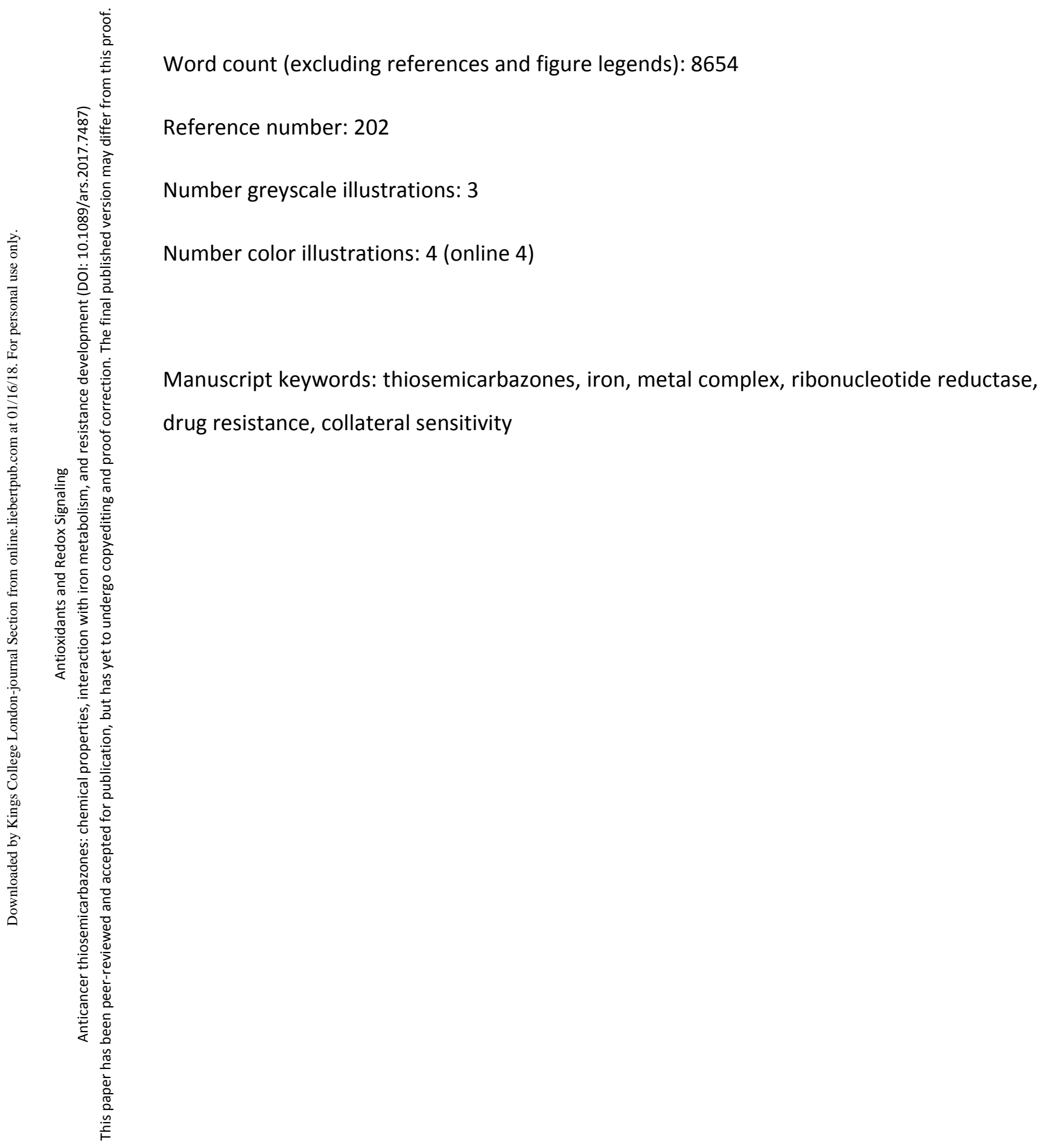




\section{Abstract}

Significance: During the last decades, thiosemicarbazones have been clinically developed for a variety of diseases including tuberculosis, viral infections, malaria and cancer. With regard to malignant diseases, the class of $\alpha-N$-heterocyclic thiosemicarbazones, and here especially Triapine, was intensively developed in multiple clinical phase I/II trials.

Recent Advances: Very recently two new derivatives, namely COTI- 2 and DpC have entered phase I evaluation. Based on the strong metal-chelating/metal-interacting properties of thiosemicarbazones, interference with the cellular iron (and copper) homeostasis is assumed to play an important role in their biological activity.

Critical Issues: In this review, we summarize and analyze the data on the interaction of ( $\alpha$ $\mathrm{N}$-heterocyclic) thiosemicarbazones with iron, with the special aim to bridge the current knowledge on their mode of action from chemistry to (cell) biology. In addition, we highlight the difference to classical iron(III) chelators such as desferrioxamine (DFO) which are used for the treatment of iron overload.

Future Directions: We want to emphasize that thiosemicarbazones are not solely removing iron from the cells/organism. In contrast, they should be considered as ironinteracting drugs influencing diverse biological pathways with a complex and multifacetted mode of action. Consequently, in addition to the discussion of physicochemical properties (e.g. complex stability, redox activity), this review contains an overview on the diversity of cellular thiosemicarbazone targets and drug resistance mechanisms. 


\section{Introduction}

During the last decades, thiosemicarbazones have been clinically developed for a variety of diseases including tuberculosis, viral infections, malaria and cancer. The first clinically approved drug of this compound class (introduced in the late 1940s) was $p$ acetamidobenzaldehyde thiosemicarbazone (Thioacetazone, Figure 1), which is still used for the treatment of multidrug-resistant tuberculosis $(40,41,140)$. The second clinically investigated thiosemicarbazone (commercialized in the 1960s) was $N$-methylisatin thiosemicarbazone (Methisazone, Figure 1), an agent developed against smallpox, which, however, due to the development of the smallpox vaccination, is not administered anymore (129). The clinical anticancer research mainly focused on $\alpha$ - $N$-heterocyclic thiosemicarbazones. As these compounds are very potent chelators for metal ions including iron, they were originally developed with the aim to target the enhanced demand of cancer cells for iron (181). Already in 1956, the first derivative, 2-formylpyridine thiosemicarbazone (FTSC, Figure 2) was reported to show activity against leukemia in mice (154). After extensive structure-activity studies the most promising compound, 5-hydroxyl2-formylpyridine thiosemicarbazone (5-HP, Figure 1), was tested in clinical phase I trials and was shown to possess anticancer activity in leukemia patients $(37,103)$. Unfortunately, these tests also revealed severe side effects (mainly gastrointestinal toxicity) and fast inactivation by glucoronidation leading to the withdrawal of the compound $(37,103)$. Further optimization led to the development of 3-aminopyridine-2-carboxaldehyde thiosemicarbazone (Triapine, 3-AP, Figure 1), a compound which has meanwhile been tested in more than 30 clinical phase I and II trials $(4,47,56,91,132)$. Similarly to the results obtained with 5-HP, Triapine showed promising activity against hematologic diseases, while solid cancers proved unresponsive. The reasons for this inefficacy of Triapine monotherapy against solid tumors are still not fully understood. Probable explanations (discussed in more detail below) include inappropriate drug delivery due to the very short plasma half-life $(47,132,143)$, fast metabolism/excretion (142) and/or rapid development of drug resistance (127). Despite these drawbacks, thiosemicarbazones have remained the focus of interest. Thus, several recent phase I studies have been performed testing the safety of Triapine in combination therapy (e.g. with cisplatin $(106,109)$, gemcitabine $(91)$, cytarabine (137), doxorubicin (163), irinotecan (26) or radiation (109)). In addition, there 
are currently two new $\alpha-N$-heterocyclic thiosemicarbazones undergoing clinical evaluation. In December 2015, COTI-2 (developed by Critical Outcome Technologies Inc., Figure 1) (159) entered a clinical phase I trial for treatment of advanced or recurrent gynecologic malignancies (NCT02433626). According to the information provided by the company, COTI-2 displays strong anticancer activity in the nanomolar range, especially in p53-mutant cell lines, as this thiosemicarbazone (comparable to some other thiosemicarbazones discovered by the $\mathrm{NCl}(78)$ ) restores the wild-type function of the p53 protein (see below). The second currently tested thiosemicarbazone is di-2-pyridylketone 4-cyclohexyl-4methyl-3-thiosemicarbazone ( $\mathrm{DpC}$, developed by Oncochel Therapeutics, Figure 1) (61), which has been under clinical phase I evaluation since January 2016 (NCT02688101) in order to assess its pharmacokinetic characteristics and the maximum tolerated dose in patients with a range of advanced and resistant tumors.

Based on these promising recent developments, the elucidation of the mechanisms underlying the (biological) activity of the different anticancer thiosemicarbazones remains of high interest. In this review we summarize and analyze the data on the interaction of ( $\alpha$ $\mathrm{N}$-heterocyclic) thiosemicarbazones with iron, with the special aim to connect the chemical properties with the current knowledge on (cell) biological modes of action. In contrast to several drugs such as desferrioxamine (DFO), which are used for the treatment of iron overload and selectively chelate iron(III), $\alpha$-N-heterocyclic thiosemicarbazones usually form stable complexes with both iron(II) and iron(III) and therefore are able to redox cycle between these two oxidation states under physiological conditions. Throughout this review we emphasize that thiosemicarbazones are not "simple" iron chelators (solely removing iron from the circulation or the cells), but in contrast have to be considered rather as iron-interacting drugs, which affect diverse biological pathways with a complex and multi-facetted mode of action. Based on the broad metal affinity, at least for some thiosemicarbazone derivatives, further biologically relevant metal ions (especially copper and zinc) have been associated with their mechanism(s) of action. However, due to the restriction in the length, this review does not comprehensively cover these additional metal ions. Furthermore, it is beyond the scope of this review to give an overview on human iron homeostasis, especially as there are several excellent reviews in literature covering this field $(24,54,87)$. 
Important physico-chemical parameters for the metal-binding ability of $\alpha-N$-heterocyclic thiosemicarbazones

Given the importance of metal binding in the biological activity of $\alpha$ - $N$-heterocyclic thiosemicarbazones, the chemical characteristics influencing their metal binding have been intensively investigated over the last few decades. These studies revealed that a profound knowledge of the solution stability, stoichiometry and redox properties of the metal complexes (especially iron(II)/(III)) under physiological conditions as well as lipophilicity or $\mathrm{pK}_{\mathrm{a}}$ of the ligands is mandatory for the understanding of structure-activity relationships of this compound class. In case of thiosemicarbazone iron complexes, the possibility to readily switch in an one-electron oxidation-reduction reaction between the ferrous form, Fe(II), and the ferric form, Fe(III) is of high importance to understand the biological effects. Consequently, the type of donor atoms which coordinate to the iron ions strongly influences not only the overall stability of the complexes but also determines if or in which electrochemical window redox cycling between the two iron oxidation states is possible.

In general, thiosemicarbazones coordinate to metal ions by a bidentate binding mode via a neutral nitrogen/sulfur $(\mathrm{N}, \mathrm{S})$ or anionic $\left(\mathrm{N}, \mathrm{S}^{-}\right)$donor set. However, metal complexes with much higher stability can be formed when an additional coordinating functionality is present in the molecule as in the case of $\alpha-N$-heterocyclic thiosemicarbazones (usually containing a pyridyl moiety) resulting in a $(\mathrm{N}, \mathrm{N}, \mathrm{S})$ donor set (Figure 2, coordinating atoms are indicated).

Unfortunately, solution stability constants have been published only for a few $\alpha-N$ heterocyclic thiosemicarbazone iron complexes, making the comparison of the different analogues difficult. So far, comparable stability data are available only for various derivatives of 2 -formylpyridine thiosemicarbazone (FTSC) including Triapine $(8,44)$ and di2-pyridylketone 4,4-dimethyl-3-thiosemicarbazone (Dp44mT) (52) with (N,N,S) donor atoms as well as salicylaldehyde thiosemicarbazone (STSC) containing an (O,N,S) donor set $(43,128)$ (Figure 2$)$. In the following sections we will summarize the available data and 
explain correlations between complex stability in solution, proton dissociation constants and redox properties.

\section{$\mathrm{pK}_{\mathrm{a}}$ values of metal-free $\alpha-\mathrm{N}$-heterocyclic thiosemicarbazones}

As a first parameter to compare different thiosemicarbazone complexes, the proton dissociation behavior of the ligands is of interest to understand the complex stability and the composition of the formed species. In general, simple $\alpha-N$-pyridyl thiosemicarbazones (such as FTSC) possess two dissociable protons. Here, the $\mathrm{pK}_{1}(\sim 3-4)$ can be attributed to deprotonation of the pyridinium unit and $\mathrm{pK}_{2}(\sim 10.5-11.5)$ to the deprotonation of the hydrazinic $\mathrm{N}-\mathrm{H}$ group of the thiosemicarbazide moiety (Figure 3 ). In case of $\mathrm{pK}_{2}$, the resulting negative charge is mainly localized on the $\mathrm{S}$ atom via the thione-thiol tautomeric equilibrium (Figure 3) and is influenced by the presence of different substituents. Thus, for example, $N$-terminal dimethylation significantly decreases the $\mathrm{pK}_{2}$ values (43). Based on the $\mathrm{pK}_{\mathrm{a}}$ values, at physiological $\mathrm{pH}$ all these $\alpha-N$-pyridyl thiosemicarbazones are charged neutral (denoted as "HL form") enabling an easier passage across the cell membrane.

\section{Characteristics of iron(II/III) thiosemicarbazone complexes}

Due to their tridentate nature, $\alpha-N$-pyridyl thiosemicarbazones form octahedral mono- and bis-ligand complexes with iron(II/III) ions resulting in species such as $\mathrm{Fe}(\mathrm{HL})$, $\mathrm{FeL}$, FeL( $\mathrm{HL}$ ), or $\mathrm{FeL}_{2}$ (where $\mathrm{L}$ is the completely deprotonated form of the ligand; Figure 3). In the protonated complexes $\mathrm{Fe}(\mathrm{HL})$ and $\mathrm{FeL}(\mathrm{HL})$, which are formed under acidic conditions, the $\mathrm{HL}$ ligand coordinates via the $\left(\mathrm{N}_{\text {pyridyl, }}, \mathrm{N}, \mathrm{S}\right)$ donor set with the proton attributed to the non-coordinating hydrazinic-N atom (44). In contrast, at neutral and basic $\mathrm{pH}$ values $\mathrm{FeL}$ and $\mathrm{FeL}_{2}$ complexes are formed, with anionic ligand(s) coordinating via $\left(\mathrm{N}_{\text {pyridyl }}, \mathrm{N}, \mathrm{S}^{-}\right)$together with deprotonation of the hydrazinic nitrogen. This was also confirmed by X-ray diffraction measurements for numerous iron(III) species $(99,102,173)$.

On the basis of the reported solution equilibrium data for the iron complexes of $\alpha$ $N$-pyridyl thiosemicarbazones (including Triapine and Dp44mT, Table 1), it can be 
concluded that at slightly acidic and physiological $\mathrm{pH}$ the $\mathrm{FeL}_{2}$-type complexes predominate $(44,52)$.

However, due to differences in the number of dissociable protons and the basicity of the ligands, the $\log \beta$ values (a cumulative formation constant for the complexes) of the iron complexes shown in Table 1 cannot be directly compared. Still, log $\beta$ values clearly show that the differences between the constants of the iron(III) and iron(II) complexes strongly depend on the type of ligand. For example, stability constants of the iron(II) and iron(III) complexes of the clinically approved iron chelator DFO (Figure 2) differ by 20 orders of magnitude. In contrast, among the group of $\alpha-N$-pyridyl thiosemicarbazones the difference is in general much smaller encompassing only $2-3$ orders of magnitude (Table 1 ). The impact of the different donor atom sets in the thiosemicarbazone structure $\left(\mathrm{N}, \mathrm{N}, \mathrm{S}^{-}\right.$vs. $\mathrm{O}^{-}$ , $\mathrm{N}^{-} \mathrm{S}^{-}$) can be demonstrated by comparing the stability of iron(II/III) complexes formed by FTSC and STSC (Figure 4). Thus, in a hypothetical metal/FTSC/STSC ternary system, the STSC ligands with the $(\mathrm{O}, \mathrm{N}, \mathrm{S}$,$) donor set have a much higher affinity for \mathrm{Fe}(\mathrm{III})$ ions, whereas the $(\mathrm{N}, \mathrm{N}, \mathrm{S})$ donor set of FTSC prefers iron(II) ions. This preference corresponds to the different hard-soft character of metal ions and the donor atoms $(87,89)$. The underlying theory behind the so-called HSAB (hard and soft acid and bases) concept (141) is that transition metals ("Lewis acids") as well as donor atoms of the potential ligands ("Lewis bases") can be classified into soft (low charge/large ionic radius), borderline, and hard (high charge/small ionic radius). According to this concept, soft acids react more efficiently and form stronger bonds with soft bases, whereas hard acids form stronger bonds with hard bases. Thus, the hard Lewis acid Fe(III) will be preferentially coordinated by the STSC ligand $(O, N, S)$ possessing the hard oxygen donor, while due to the softer $(N, N, S)$ donor set, $\alpha-N$-pyridyl thiosemicarbazones are unambiguously more efficient chelators of iron(II).

Beside the type of the coordinating donor atoms, also substituents on the thiosemicarbazone backbone can distinctly modify the stability of the respective metal complexes. For example, the iron(II)-binding ability of FTSC is weaker compared to that of 
Triapine, which in turn is weaker than that of the $\mathrm{N}$-terminally dimethylated 2formylpyridine thiosemicarbazone (PTSC) (44). Notably, the iron(II)-binding ability is in strong correlation with the anticancer activity of the compounds, with PTSC being the compound with the highest and FTSC the lowest cytotoxicity (in the $\mathrm{nM}$ and $\mu \mathrm{M}$ range, respectively) (102). This correlation also fits to the much lower stability of the STSC iron(II) complex and its low cytotoxic activity $(45,117,148)$. Overall, these data highlight the importance of the iron(II)-binding affinity of thiosemicarbazones in the optimization of their anticancer effects. However, it has to be considered that the analytical data for determination of the complex stability are usually measured in a concentration range of $\sim 10 \mu \mathrm{M}$ to $1 \mathrm{mM}$. Consequently, binding affinities in the low $\mu \mathrm{M}$ to $\mathrm{nM}$ range are based on extrapolations, which make a profound estimation of the interaction of thiosemicarbazones with iron ions especially in the low $\mathrm{nM}$ range very difficult. This is especially of relevance in case of several highly active derivatives such as PTSC (42), DpC (116), and Dp44mT (14), in which $N$-terminal dimethylation (or more general dialkylation) results in a dramatically increased cytotoxic activity as compared to derivatives with an unsubstituted terminal $\mathrm{NH}_{2}$ moiety (e.g. FTSC and Triapine). In case of these thiosemicarbazones, we can only speculate, whether they are indeed still able to bind iron(II)/(III) ions at their nanomolar $\mathrm{IC}_{50}$ concentrations. Noteworthy, detailed structureactivity relationship studies revealed that this increased activity only occurs if no $\mathrm{NH}_{2}$ or even $\mathrm{NH}$ group (with the exception of the hydrazinic $\mathrm{NH}$ ) is present in the molecule $(101,102)$. Consequently, the terminally dimethylated derivative of Triapine has a cytotoxic activity comparable to Triapine itself (102) and only dimethylation of both amino groups results in a nanomolar activity (101). However, the underlying mechanisms and the role of iron complexation in this highly increased cytotoxic activity are widely unknown. There are some indications that thiosemicarbazones being active in the nanomolar concentration range are characterized by an additional mode of action (and also induce different resistance patterns), which might involve interaction with copper, which is discussed in more detail below $(53,83,101)$. 


\section{Solution stability and redox potential}

The ratio between the cumulative stability constants of the iron(II) and iron(III) complexes is strongly connected to the redox potential. The reason is that the formal redox potential $\left(\varepsilon^{\prime}\right)$ of the $\mathrm{Fe}(\mathrm{III}) / \mathrm{Fe}(\mathrm{II})$ redox couple is determined by the ratio of the cumulative stability constants of the iron(III) and the iron(II) complexes according to the general Eq.1.(172)

$\varepsilon^{\prime}{ }_{\mathrm{Fe}(I I I) c o m p l e x / \mathrm{Fe}(I I) c o m p l e x}-\varepsilon^{\prime}{ }_{\mathrm{Fe}(I I I) a q u a / F e(I I) a q u a}=-59.15 \times \log \left(\beta_{\mathrm{Fe}(I I I) c o m p l e x} / \beta_{\mathrm{Fe}(I I) c o m p l e x}\right) \quad$ (Eq.1).

Therefore, an increasing formal potential obtained at $\mathrm{pH} 7.4$ represents an increasing affinity of the ligand towards iron(II) compared to iron(III) (Table 2). As a consequence, e.g. the iron complexes formed with the aromatic nitrogen donor atom-containing bidentate ligand 1,10-phenantholine (Figure 2) are characterized by a very high formal potential of the iron complex (+1140 mV vs. normal hydrogen electrode (NHE) (113)) and, therefore, the iron(III) complex shows low stability in aqueous solution (122). In contrast, the iron complexes of chelators applied for the treatment of iron overload such as DFO, deferiprone and deferasirox (Figure 2) are characterized by very low redox potentials (Table 2) and, consequently, very high iron(III)-binding abilities (reflected by high pM values, which is the negative logarithm of the equilibrium concentrations of the unbound metal ion). For example, in case of DFO, which has a formal redox potential of $-482 \mathrm{mV}$ vs. NHE (172), the iron(II) complex has much lower stability compared to the respective iron(III) complex $(46,69)$. Under anaerobic conditions (at physiological pH) DFO is even able to oxidize iron(II) to iron(III) (46). The reason for this behavior is that these agents mainly contain hard oxygen donor atoms, which are ideal for iron(III) binding $(87,89)$. This feature results in a very high binding efficacy and provides the enormous selectivity of these ligands for iron(III), not only in comparison to iron(II) but also to other essential bivalent metal ions like zinc(II) and copper(II). In addition, due to the low $\varepsilon^{\prime}$ values, iron complexes of these chelators do not redox cycle under physiological conditions (76) preventing generation of reactive oxygen species (ROS) via Fenton-type reactions. 
In contrast to the (mainly oxygen-containing) chelators developed for the treatment of iron overload, anticancer $\alpha-N$-pyridyl thiosemicarbazones such as Triapine, DpC or Dp44mT coordinate metals via their $\left(\mathrm{N}_{\text {pyridyl }}, \mathrm{N}, \mathrm{S}^{-}\right)$donor set. As a result of this binding mode, the redox potentials of their iron complexes are significantly higher (in the range of $-170 \mathrm{mV}$ to $+170 \mathrm{mV}$ vs. $\mathrm{NHE})(44,155)$ compared to DFO, deferiprone or deferasirox $(-482 \mathrm{mV}$ to $620 \mathrm{mV}$ vs. NHE; see Table 2). Consequently, $\alpha-N$-pyridyl thiosemicarbazones show a considerably high affinity towards both iron(II) as well as iron(III) ions. This property enables the iron thiosemicarbazone complexes to redox cycle between the two oxidations states, as these redox potentials are accessible to intracellular oxidants and reductants $(66,87,155)$. Redox cycling is considered as an important factor in the antiproliferative activity of these compounds (although the correlation between the redox potential and cytotoxicity is not as evident as the relation between stability and cytotoxicity). In line with the relevance of redox cycling for anticancer thiosemicarbazones, iron(III)-specific chelators such as DFO are generally not efficient antitumor agents and can be safely used to treat iron overload $(23,116,197)$. This already indicates that "iron depletion" in itself is not sufficient to explain the anticancer activity of thiosemicarbazones.

\section{Interaction of thiosemicarbazones with the body iron}

Based on the above-described features of thiosemicarbazones, there is no doubt that interaction with iron plays an important role in the biological activity of Triapine as well as many other $\alpha-N$-heterocyclic derivatives. In addition to cell culture studies (discussed in more detail below), which investigated the role of iron and other metal ions in the activity of thiosemicarbazones on a cellular level, there are reports from clinical trials on the interaction of thiosemicarbazones with iron metabolism. For example, in case of 5-HP, excretion of the green-colored iron complex was observed in the urine of treated patients within a few hours after drug administration (103). In contrast, in Triapine-treated patients (or animals) $(47,132,143)$ ) no coloring of urine but methemoglobin formation (oxidation of iron(II) to iron(III) in hemoglobin) was observed which is a prominent indication for its interaction with body iron. This type of adverse effect, observed in $\sim 23 \%$ of Triapine- 
treated patients $(94,107)$, was also reported for several preclinically developed $\alpha-N$ heterocyclic thiosemicarbazones such as Dp44mT (150) (in this study methemoglobin formation was analyzed in mice as well as in isolated human red blood cells) (Table 3). With regard to the underlying mechanism, the iron(III) complex of Triapine is believed to oxidize the iron(II) in the hemoglobin molecule by direct electron transfer (183). In line with the supposed role of a redox reaction in the thiosemicarbazone-induced methemoglobin formation, clinical trials with Triapine additionally indicated that patients with a glucose-6-phosphate deficiency suffered from enhanced methemoglobin levels and even hemolysis after treatment (199). Since glucose-6-phosphate is important in the protection of red blood cells from oxidative stress (184), this supports the assumption that Triapine treatment interferes with redox homeostasis. Methemoglobin formation seems to be strongly dependent on the interaction of the terminally unsubstituted $\mathrm{NH}_{2}$ groups of the thiosemicarbazone iron complexes with the carboxylic acid groups of the porphyrins of hemoglobin (Figure 5) (11,12,143). Consequently, novel $\alpha$-N-heterocyclic thiosemicarbazones such as DpC (and probably also COTI-2) carrying a bulky substituent at this position are far less potent methemoglobin inducers than their predecessors (12).

Besides methemoglobin formation, also other iron-associated biological parameters were affected by Triapine treatment. Wadler et al. (186) described that after $96 \mathrm{~h}$ of continuous Triapine infusion serum iron and ferritin levels transiently increased by $104 \%$ and $77 \%$, respectively. Remarkably, the total iron-binding capacity of the blood remained unchanged in these patients, indicating that there was no net loss of iron from the body. Consequently, the authors concluded that (in contrast to 5-HP or the traditional iron(III) chelators (103)) Triapine-bound iron might be recovered during its hepatic metabolism and the increased delivery of iron to the liver could induce production of ferritin explaining the elevated serum levels of this protein. Interestingly, despite these distinct impacts on several iron-associated clinical parameters, all attempts to detect the formation of an ironTriapine complex in vivo or even in cell culture have failed so far $(95,96,143)$. 


\section{Cancer-associated cellular targets of thiosemicarbazones}

\section{1) Ribonucleotide reductase}

The iron-containing enzyme ribonucleotide reductase (RR) is most probably the best described target of anticancer $\alpha$-N-heterocyclic thiosemicarbazones (Table 3). This metalloenzyme catalyzes the conversion of ribonucleoside diphosphates (NTPs) to deoxyribonucleoside diphosphates (dNTPs). Therefore, it is crucial for DNA synthesis as well as DNA damage repair and is frequently overexpressed in cancer cells making it an attractive target for treatment. The RR is a tetrameric protein composed of two large subunits (hRRM1) that are important for substrate binding, and two small iron-containing R2 subunits being responsible for its enzymatic function $(5,25)$. Two different R2 subtypes have been described: i) the hRRM2 subunit, which is a cell cycle-dependent protein, strongly upregulated at the beginning of the S-phase and actively degraded via ubiquitination during the $\mathrm{G} 2$ phase of the cell cycle (60); ii) p53R2 (also called hRRM2B), a subunit which is expressed at lower levels than hRRM2 but is not degraded during mitosis (138) and therefore its levels remain constant during the cell cycle. In addition, reports suggest that expression of this subunit can be induced in a p53-dependent manner. Consequently, it is assumed that the so formed protein is involved in several cellular functions including DNA repair, cell cycle arrest and mitochondrial homeostasis $(5,25)$.

Inhibition of the tyrosyl radical in the active center of the hRRM2/p53R2 subunit was demonstrated for several thiosemicarbazones (including Triapine and Dp44mT) as well as diverse iron chelators (like phen and DFO) mainly in cell-free systems $(6,59,74,99,167,178,198,202)$. The best-investigated thiosemicarbazones with regard to RR inhibition are Triapine and its closest analogs, for which detailed in vitro studies were performed during the last decades. In addition, a phase I trial with Triapine demonstrated the depletion of dATP and dGTP pools together with a decrease of DNA synthesis in circulating leukemia cells (56).

With regard to the mechanism, it was initially assumed that Triapine inhibits the hRRM2 subunit through iron chelation, either from the active site of the protein or from the 
cellular labile iron pool (5). However, this theory was questioned by several observations indicating that in fact Triapine seems to be a surprisingly inefficient iron chelator in cell culture. For example, it was shown that, in contrast to DFO, Triapine had a relatively weak effect on cellular transferrin receptor levels of SK-N-MC cells (23) perhaps due to the weaker iron(III)-binding ability compared to DFO. Also, electron paramagnetic resonance (EPR) spectroscopic analyses of Triapine-treated K562 cells (5 or $500 \mu \mathrm{M}$ ) showed no change in the size of the $g=4.3$ signals (typical for intracellular iron-chelate complexes) after $0.5,3$ and $12 \mathrm{~h}$ of treatment, which would be indicative for depletion of the intracellular iron(III) pools (6). The same authors showed that in the presence of Triapine the loss of iron bound inside the RR molecule was five times lower than the destruction of the tyrosyl radical $(5,6)$ and subsequent investigations of Triapine-treated COS-1 cells indicated iron-loaded hRRM2 (with a quenched tyrosyl radical) as the main remaining protein species, arguing against iron chelation from the enzyme. Moreover, in these COS-1 cells Triapine did not change the aconitase activity (6). This is of interest, as this protein contains an essential [4Fe4S] cluster, which is ROS-sensitive and could be influenced by depletion of the labile iron pool (6). Consequently, the authors of this study concluded that Triapine is not only ineffective in sequestering iron inside the cell, but also that it is unlikely to be involved in disruption of biosynthesis or repair of metallo-cofactor-requiring proteins (6).

Based on the repeated observations, that in cell-free systems metal-bound Triapine (particularly the iron(II) complex) possesses a dramatically increased ability to inhibit hRRM2 compared to the metal-free ligand $(6,146,167,202)$, several authors speculated that the active species responsible for cell killing is in fact the iron complex of Triapine. In more detail, it was assumed that upon intracellular formation of the redox-active iron complex, ROS are generated, which are ultimately responsible for RR inhibition (167). Interestingly, the pronounced activity of Triapine and close derivatives against hRRM2 in the presence of iron was not observed in cell-free systems of p53R2, and co-incubation with iron had even protective effects against the inhibition of this enzyme (202). Furthermore, there are several reports suggesting that at biologically active concentrations no substantial ROS generation was detected after treatment with metal-free Triapine or 
other close derivatives $(100,115,134)$. In line with these observations, recent studies have revealed no oxidation of $\mathrm{hRRM} 2$ residues or the accumulation of oxidized cellular proteins (neither in cell-free nor in cell culture experiments) after Triapine treatment, suggesting that global ROS generation might not be mandatory for RR inhibition by Triapine $(5,6)$. Notably, as already mentioned before, despite several attempts $(96,143)$ intracellular formation of a Triapine-iron complex has not been directly demonstrated either in vitro or in vivo. Taken together, while the importance and necessity of iron-binding in the anticancer activity of thiosemicarbazones is proven without doubt (derivatives and metabolites lacking a metal-binding domain are completely inactive $(142,147,200))$, the exact mode of action remains elusive.

Consequently, several alternative theories have been published to offer an explanation how Triapine could inhibit the RR without the direct chelation of the enzyme-bound iron or the production of ROS. On the one hand, it was suggested (comparably to the interaction with hemoglobin in the methemoglobin formation) that the iron(II) complex of Triapine could act as reductant, directly reducing the tyrosyl radical of the hRRM2 subunit (6). This is of interest as direct binding of Triapine to hRRM2 and p53R2 was shown by radioactive labelling (202), which was only slightly affected by addition of iron. In line with these experimental data, docking studies of mouse RR revealed a possible Triapine-binding site with the pyridine ring of the thiosemicarbazone located in the pocket of the four amino acids Phe237, Phe241, Ser238 and Tyr324 (146). Based on these results, it can be hypothesized that, following the binding of (metal-free) Triapine to the enzyme, an iron complex is formed locally, using the iron liberated during each catalytic cycle of the RR. Another possible mechanism is based on the effect of Triapine on intracellular thiol homeostasis. Here, especially the effects on the thioredoxin system seem to be of importance, as thioredoxin ( $\operatorname{Tr} x$ ) or glutaredoxin are necessary to reactivate the RR enzyme after the end of each reaction cycle. In detail, during the conversion cycle of NTPs to dNTPS a disulphide bond is formed in the hRRM1 subunit, which has to be reduced before the RR can enter a new enzymatic cycle $(60,166)$. Some reports indicate that Triapine as well as Dp44mT inhibit thioredoxin reductase $(\operatorname{TrxR} 1)(134,198)$. However, as these effects were observed only at very high concentrations (>50-fold above the $I C_{50}$ values (133)), it remains 
16

unclear whether this is of biological relevance. Interestingly, murine L1210 leukemia cells selected for resistance against 4-methyl-5-amino-1-formylisoquinoline thiosemicarbazone (MAIQ) were (besides the overexpression of several efflux pumps (29)) also characterized by overexpression of protein disulfide isomerases (PDI) (30), which are thiol oxidoreductase chaperones from the thioredoxin superfamily (171).

\section{2) Impact of thiosemicarbazones on the cell cycle and other (iron-dependent) cellular pathways.}

During the last decades, it has been repeatedly reported that treatment with diverse iron chelators leads to cell cycle arrest in $\mathrm{G}_{0} / \mathrm{G}_{1}$ or early $S$-phase $(27,71,79,147,151,170)$. One explanation certainly is the above-described inhibition of the RR. However, several other proteins involved in DNA replication and repair also require iron as a cofactor and thus could be influenced by thiosemicarbazones and other iron-chelating drugs. These proteins include for example three DNA polymerases (Pol $\alpha$, Pol $\delta$ and Pol $\varepsilon$ ), several DNA helicases (including Rad3/XPD, Dna2, RTEL1, FANCJ and ChIR1) as well as the DNA primase regulator subunit PRIM2 (201). In contrast to RR, these polymerases, helicases and primases contain an Fe-S cluster, which is necessary for the formation of active holoproteins (201). Interestingly, inhibition of RNA polymerases seems to be very important for the antiviral activity of several thiosemicarbazones, indicated by point mutations in the enzymes leading to drug-resistant virus variants $(20,21,31,149)$. However, there are only a few studies (based on cell-free systems) linking polymerase inhibition to cancer (63) and to our knowledge there is so far no indication that inhibition of polymerases also occurs in cancer cells after thiosemicarbazone treatment. Likewise, the activity of the [4Fe-4S] clustercontaining aconitase (201) is not affected by Triapine (6), indicating that, in general, human Fe-S cluster proteins are not (heavily) affected by thiosemicarbazone treatment.

In addition to its direct role in proteins executing DNA synthesis, iron also influences cell cycle regulation via cyclins and cyclin-dependent kinases (CDKs) (201). Thus, it has been repeatedly reported that treatment with diverse iron chelators such as DFO or L-mimosine (an amino acid derivative and predecessor of deferiprone) and also thiosemicarbazones 
results in the downregulation of cyclin $A$ and $D(7,23,27,105,110,136)$ as well as CDK2/4 $(23,35,36,105)$ (Table 3$)$. Overall, the mechanisms underlying these effects are not fully understood and there might be several explanations. For example, in case of CDK2 it was reported that binding of iron ions to the protein occurs only to its phosphorylated form, indicating a direct regulation of this protein by the cellular metal homeostasis (9). With regard to cyclin $A$, little is known about the mechanisms explaining how thiosemicarbazones could influence the expression levels of this protein. Of interest in this context might be a recent report on the downregulation of cyclin A (in addition to cyclin D) by rolipram, a PDE4 inhibitor (121), which also strongly protects cells from Triapine treatment. In addition, loss of PDE4D was the only genomic alteration found in Triapineresistant SW480 cells (126). With regard to its biological function PDE4 is a negative regulator of cyclic AMP (cAMP), which in turn is one of the most abundant second messengers regulating various physiological processes like cell survival, differentiation, proliferation and apoptosis (10). One major downstream target of CAMP is CAMPdependent protein kinase (protein kinase A, PKA), which then activates the transcription factor cAMP responsive element-binding protein (Creb) (157). Consequently, interaction of thiosemicarbazones with this regulatory pathway could also serve as an explanation for the observed effects on cyclin A.

More information is available on the mechanisms linking disturbed cellular iron homeostasis to the reduced expression of cyclin D1. For example, DFO and 311 (2-hydroxy1-naphthylaldehyde isonicotinoyl hydrazine, a congener of $\mathrm{PIH}$ ) resulted in active degradation of cyclin D1 (136), whereas DpC (and in some cell lines also Dp44mT) downregulated the expression of cyclin D1 by inhibition of STAT3 dimerization and activation (possibly via inhibition of upstream kinases such as Src and Abl) $(119,187)$. Interestingly, the described effects were similar for the metal-free ligands and preformed iron complexes. In addition to STAT3, treatment with DFO (110), deferasirox (120), Lmimosine (27), as well as Dp44mT $(110,114,120,187)$ and DpC (97) downregulated cyclin D1 also via $N$-myc downstream-regulated gene 1 or 2 (NDRG1/2), repeatedly shown in cell culture and for some drugs also in mouse models (Table 3). However, NDRG1 also has multiple other cellular targets including the TGF $\beta$, the Wnt/ $\beta$-catenin (114), the 

FAK/paxillin (188), the NF-KB (192), and the ErbB signaling pathways (98). Consequently, it is not surprising that besides inhibition of cell cycle progression, the drug-mediated stimulation of NDRG1/2 can be linked to several other effects including reduced aggressiveness or metastatic potential, which has been described e.g. for Dp44mT- or DpCtreated hepatocellular and breast carcinoma cells $(114,187)$. Interestingly, NDRG1 has recently also been identified as downstream-target of the above mentioned PKA/CREB signaling axis (81). Finally, cyclin D1 is also a well-known target of p21 $1^{\text {waf }}$, which was reported to be stimulated by diverse iron(III) chelators including DFO, deferasirox, 311, but also Dp44mT, DpC, and TSC24 (N,N-dimethyl-2-(quinolin-2ylmethylene)hydrazinecarbothioamide, a terminally dimethylated analogue of FTSC) $(7,23,32,97,120)$. P21 ${ }^{\text {waf }}$ is a down-stream target of the DNA damage sensor p53 (78). Considering, the enhanced DNA damage (indicated for example by phosphorylation of the damage marker $\mathrm{H} 2 \mathrm{XA}$ ) which was observed after treatment with different RR inhibitors (including Triapine, Dp44mT) in cell culture $(83,108,138,151)$ but also in mouse models (unpublished results from our group), it is not unexpected that stimulation of p53 expression has been described for some RR inhibitors $(112,131)$ (Table 3$)$. However, there is a surprisingly low number of reports on p53 activation by thiosemicarbazones and no correlation between p53 status and anticancer activity was found for several Dp44mT derivatives or Triapine $(189,196)$. This led (at least in case of Dp44mT) to the suggestion that mouse double minute 2 homolog (MDM2)-mediated protein degradation could be responsible for $\mathrm{p} 53$-independent $\mathrm{p} 21^{\text {waf }}$ regulation (131). Nevertheless, Yu et al. identify three thiosemicarbazone derivatives (NSC319725 and NSC319726, both terminally substituted FTSC derivatives, as well as NSC328784, a selenosemicarbazone derivative of COTI-2) in the $\mathrm{NCl60}$ screen database, which showed preferential anticancer activity in p53-mutant cell models harboring the R175 mutation (196). Subsequent analysis revealed that these effects are based on the restoration of a p53 "wild type-like confirmation" in an iron-sensitive manner (in case of $\mathrm{NSC} 19726$ addition of $\mathrm{FeSO}_{4}$ completely abrogated the activity) (196).

Interestingly, there are also reports on the interaction of cyclin D1 with the mitochondrial regulation (145). Thus, knock-out of cyclin D1 leads to increased mitochondrial size and 
activity. Accordingly, inactivation of the CDK/cyclin substrate Rb and overexpression of p21 resulted in inhibition of the mitochondrial metabolism (145). Furthermore, there are several heme proteins such as cytochromes or nitric oxygenase, which are crucial for mitochondrial function (201). In line with this, there are some reports how thiosemicarbazones affect the mitochondria. On the one hand, induction of apoptosis via the intrinsic (mitochondria-mediated) pathway has been described for diverse representatives of this compound class $(1,7,97,144,147,170,200)$. However, as thiosemicarbazones induce apoptosis usually only at quite high drug concentrations (far above the $\mathrm{IC}_{50}$ values), they can be considered rather as cytostatic agents which mainly execute their activity via cell cycle arrest. On the other hand, at least for Triapine and Dp44mT also a perturbation of the mitochondrial redox homeostasis was reported $(133,134)$. Thus, treatment resulted in oxidation of mitochondrial Trx2 and, subsequently, the inability of the treated cells to maintain the redox state of Trx2-dependent proteins such as peroxiredoxin 3 (Prx3) (134) (Table 3). In line with these findings, Triapine treatment was distinctly more efficient in cells with Prx3 and Trx2 knockdown (134). However, in this study no signs of global redox stress in the cytosol of Triapine-treated cells were detected (134). Thus, for example several cytosolic redox proteins like Trx1, and Prx1, or endoplasmic Prx4 remained unchanged at clinically relevant concentrations (low $\mu \mathrm{M}$ range) (133). This preferential oxidation of mitochondrial Trx2 and Prx3 after Triapine treatment could be explained by an organelle-specific accumulation of the iron(III) complex of Triapine, as lipophilic cations can accumulate at several hundred-fold higher levels inside the mitochondria because of the large mitochondrial membrane potential (134). On the other hand, it is also possible that Triapine increases the mitochondrial peroxide (or other ROS) levels that may directly promote Prx3 oxidation. Also in case of Dp44mT (and to some extent DFO), interaction with the mitochondria was indicated by reports of treatment-induced upregulation of adenosine monophosphate-activated protein kinase (AMPK) a protein which is important for the restoration of the cellular energy levels (104) at low ATP levels, e.g. in response to mitochondrial dysfunction or stress (82). 
Besides inhibition of cell cycle progression and (to some extent the induction of apoptotic cell death), more recently also induction of ER stress and autophagy have been described for several thiosemicarbazones (e.g. Triapine and it's terminally dimethylated derivative PTSC (180), Dp44mT $(111,125,158)$ as well as a combination of DpC with $N, N_{,} N^{\prime}, N^{\prime}-$ tetrakis-[2-pyridylmethyl]-ethylenediamine (195)) in cancer cells. However, autophagy induction was also reported for two thiosemicarbazones, which are unlikely to form stable metal complexes (2-(acridin-9-ylmethylene))- $N$-phenylhydrazinecarbothioamide in breast cancer cells (33) and 4-nitrobenzaldehyde thiosemicarbazone in leishmania (162)), indicating that this mode of action is not primarily attributed to their interaction with cellular metal metabolism.

\section{Copper(II) complexes of thiosemicarbazones}

Due to the generally strong metal-binding properties of thiosemicarbazones, besides their interaction with iron(II/III) ions also complex formation with other biologically relevant metals has been repeatedly suggested $(87,90)$. In this respect, especially copper complexation has been discussed in the mode of action for several thiosemicarbazones, as both $\alpha$-N-pyridyl- and salicylaldehyde-type thiosemicarbazones form mono-ligand copper(II) complexes with very high stabilities (43-45). In fact, thiosemicarbazones have typically a much stronger affinity towards copper(II) ions compared to iron ions and the stability of the formed copper(II) complexes e.g. for Triapine is so high that their decomposition at $\mathrm{pH} 7.4$ even at $1 \mu \mathrm{M}$ concentration is negligible ( $\leq 1 \%)(43)$. In line, for Dp44mT a strong preference for copper complexation compared to iron(II) or zinc(II) was reported (53). In contrast to the trend observed for the iron complexes, in case of copper(II), $\mathrm{N}$-terminal dimethylation of the thiosemicarbazone ligands had only minor effects on the complex stability (39). However, it has to be considered that intracellular iron is rather easily accessible via the labile iron pool, whereas under healthy conditions "available" copper cannot be found as most of the copper is protein-bound.

During the last decades, multiple cell culture studies have been performed investigating the anticancer activity of preformed copper thiosemicarbazone complexes 
$(2,17,85,135,161)$. Here, generation of ROS based on the reduction of $\mathrm{Cu}(\mathrm{II})$ to $\mathrm{Cu}(\mathrm{I})$ by intracellular reducing agents is so far assumed to be the major mode of action underlying the anticancer activity of such copper(II) thiosemicarbazone complexes $(2,17,85,135,161)$. However, our own studies indicated that this might not be a general rule, as for example in case of Triapine, the intracellular milieu seems not to be sufficient to allow significant redox cycling and ROS generation of the respective copper(II) complexes (100).

With regard to metal-free ligands and their cellular interaction with copper, the available data are quite controversial. As already mentioned above, there are several reports stating that at $I C_{50}$ concentrations no signs of global ROS formation (e.g. by using DCF-DA stains) were detectable when metal-free thiosemicarbazone ligands were used $(100,115,134)$. Moreover, similarly to iron thiosemicarbazone complexes, so far no experimental proof of intracellular copper complex formation exists. Both aspects could be explained by a lowlevel and organelle-specific formation of such complexes. Consequently, in case of Dp44mT (and its derivatives), for which an important role of copper has been proposed, Lovejoy et al. suggested that due to its "polyprotic nature" Dp44mT as well as its copper complex are specifically trapped in the acidic lysosomes (115). However, detailed solution equilibrium studies proving this hypothesis are still missing. This lysosomal accumulation subsequently leads to oxidative damage of the lysosomal membrane and induction of lysosomal cell death (62).

In general, it can be summarized that intracellular complex formation of thiosemicarbazones with copper(II) ions is mainly discussed for terminally di-alkylated thiosemicarbazones like Dp44mT and DpC, which are characterized by cytotoxic activity in cell culture in the nanomolar range. These compounds also show a very strong synergistic activity with copper(II) salts, in contrast to thiosemicarbazones like Triapine with even antagonistic effects with copper(II) $(83,101)$. As the stability of the copper(II) complexes, however, does not seem to be the crucial parameter, other factors like the thermodynamics and kinetics of the reduction process in the cellular environment are probably more important in this aspect. 


\section{Drug resistance - background}

Drug resistance is still one of the main reasons for the failure of anticancer therapies, especially at the late stage of the disease, when tumor cells have spread throughout the patient's body (67). Even in case of novel targeted therapeutics such as tyrosine kinase inhibitors that were designed based on the increased understanding of the so called "cancer hallmarks" $(67,68)$, clinical trials of the last 15 years proved that cancer cells can rapidly become resistant through multiple mechanisms $(15,55,57,58,88,92,190)$. The challenges experienced with targeted therapeutics highlight the importance of research on traditional chemotherapeutic approaches. Given the complexity and heterogeneity of cancer, "dirty drugs" targeting multiple enzymes may avoid resistance mechanisms limiting the success of existing treatment schemes (48). Several chemotherapeutics have been shown to modulate more than a single molecular target or pathway, suggesting that such a promiscuous behavior may be key to long-term therapeutic efficiency $(3,16)$. Also metalinteracting drugs, including thiosemicarbazones hit multiple targets related to tumor growth, drug resistance and metastasis ("triad of death", see (84)), which is why they are considered as prime examples of the success and promise of "polypharmacology". As described above, the mechanisms of action of anticancer thiosemicarbazones are not entirely understood - and unfortunately even less is known about mechanisms of resistance against these drugs.

In general, drug resistance can be classified into two types (72). On the one hand, tumor cells might prove unresponsive to therapy already at the first treatment ("intrinsic drug resistance"). On the other hand, drug-resistant tumors can arise following initial response to therapy ("acquired resistance") (72). Several resistance mechanisms inhibit the delivery of drugs to their cellular target. Reduced delivery can be based on the tumor-specific microenvironment (e.g. poor vascularization of the malignant tissue) or cellular mechanisms spanning from enhanced drug efflux, reduced drug uptake, altered drug distribution to (especially in case of targeted therapeutics) target mutation/modification resulting in loss of binding and steric hindrance (Figure 6) $(58,72,88,92)$. Even if the target is reached, tumor cells may still survive by the inactivation of programmed cell death execution pathways, enhanced damage repair (in case of DNA-damaging agents) or 
upregulation of oncogenic by-pass mechanisms (in case of targeted drugs) (Figure 6) $(58,72,88,92)$. In addition, activation of cell cycle checkpoints can contribute to survival during therapy. A frequently observed problem is the occurrence of multi-drug resistance (MDR), when cells become cross-resistant to multiple structurally and mechanistically unrelated drugs (57). The most prominent and best-understood MDR mechanism is the active drug export due to the overexpression of efflux pumps (ATP-binding cassette (ABC) transporters). This family of ATP-driven, membrane-spanning proteins is involved in the transmembrane transport of a vast array of potentially toxic molecules that include toxins, peptides, sugars, lipids, but also chemotherapeutics and diverse pharmaceutical agents $(34,49,57,177)$. Cancer cells frequently hijack these physiological protection mechanisms to shield themselves from the toxic insult of therapy $(72,160)$. In particular, anticancer drug resistance has been linked to the overexpression of P-glycoprotein ( $A B C B 1)$, multidrug resistance-associated proteins 1 and 2 (MRP1/2, ABCC1/2) and the breast cancer resistance protein (BCRP, ABCG2) (176).

\section{Resistance against thiosemicarbazones}

As already pointed out above, results of clinical trials assessing the activity of Triapine, especially in solid tumors, were overall rather disappointing. One important aspect is the rapid excretion and, thus, very short plasma half-life of this thiosemicarbazone $(<1 \mathrm{~h}$ in humans) $(56,91,143,186)$. Given the cytostatic (rather than cytotoxic) activity of Triapine, one could hypothesize that the transient Triapine plasma levels are insufficient for efficient drug delivery and long-lasting RR inhibition in solid tumor nodules. Moreover, as mentioned above, cancer cells can adapt to treatment by transiently arresting proliferation through the activation of cell cycle checkpoints, until the drug levels are below pharmacologically active concentrations.

In order to better understand the mechanisms leading to resistance to thiosemicarbazones, several representatives have been studied using in vitro models, typically based on cell lines cultured in the presence of increasing concentrations of the thiosemicarbazone. Early studies on a murine leukemia cell line selected for resistance against MAIQ suggested that Triapine is recognized and transported by $A B C B 1$ and $A B C C 1$ $(29,152)$ (interestingly, this cell line was later described to additionally overexpress 
disulfide isomerase, a protein of the thioredoxin superfamily (30)). Similarly, screening of diverse compounds resulted in a number of other thiosemicarbazones, which were found to be substrates for $A B C B 1(65,127), A B C G 2(38,73)$ or other (non-human) $A B C$ transporters $(13,18)$. Also the Triapine-resistant SW480 cell line developed in our lab showed massive overexpression of $A B C B 1$ via activation of phosphokinase $C$ (PKC) (127). However, in contrast to the above mentioned previous report (152), Triapine proved to be only a weak $A B C B 1$ substrate in two human MDR models and $A B C B 1$ inhibition did not resensitize the Triapine-resistant SW480 cells to thiosemicarbazone treatment (127). In contrast, as already described above, the resistance in Triapine-resistant SW480 cells was based on the hyper-activation of the CAMP-signaling pathway (126). Interestingly, some reports suggest that common $A B C B 1$ (and $A B C C 1$ ) haplotypes may influence sensitivity of patients to Triapine treatment $(26,179)$. Thus, patients with wild-type ABCB1 exhibited higher plasma levels along with an increased occurrence of dose-limiting toxicities (26), while the C3435T variant was associated with prolonged overall survival (179). Unfortunately, since tumoral $A B C B 1$ levels were not assessed, it remains unclear whether tumor-associated $A B C B 1$ had impact on the response in these clinical trials.

Especially with regard to drug resistance and the impact of $A B C$ transporters, strong structure-activity relationships were observed for several thiosemicarbazones indicating that already small modifications of the structure may result in distinct changes of the drug resistance profile. For example, methylation of the pyridine- and terminal amino-groups of Triapine resulted in increased activity against Triapine-resistant SW480 cells (101). In addition, $\mathrm{N}$-terminal dimethylation of Triapine derivatives led to recognition by ABCC1 as well as ABCG2 and (probably glutathione-associated) efflux from resistant cancer cells (73), resulting in distinct differences in the resistance pattern of the derivatives being active at nanomolar concentrations compared to other thiosemicarbazones. Interestingly, structural modification of certain isatin-derivatives led to an increased, rather than decreased activity in $A B C B 1-o v e r e x p r e s s i n g ~ c e l l ~ l i n e s ~(80,118)$. This phenomenon is called "collateral sensitivity" and will be discussed in more detail in the next section.

As already indicated in the chapter above, drug resistance is frequently associated with changed intracellular drug levels. Besides enhanced efflux (most prominently via $A B C$ 
transporters) also reduced drug uptake is frequently observed (72). For example, in case of the clinically approved drugs cisplatin and carboplatin, the copper transporter 1 (Ctr1) seems to be responsible for cellular accumulation and consequently, cells with acquired drug resistance were characterized by Ctr1 downregulation. Notably, also the isatin-6thiosemicarbazone NSC73306 has been identified as a Ctr1 substrate (and its uptake was blocked by cisplatin coincubation) (50). Moreover, in case of Dp44mT and other derivatives of the DpT class (but not Triapine or most derivatives of the BpT or ApT series), uptake via a carrier-/receptor-mediated mechanism was suggested (125). It is still a matter of debate $(124,193)$, whether the (rather weak) albumin binding of Dp44mT is involved in this cellular uptake mechanism. Nevertheless, it is interesting that in several cell lines coincubation of Dp44mT with human serum albumin resulted in enhanced cellular uptake of the thiosemicarbazone (124). A possible explanation is the (direct) interaction of albumin with Ctr1 $(93,168)$, which could point towards a role of Ctr1 also in the uptake of Dp44mT. However, as knockdown of Ctr1 did only marginally affect the sensitivity of KB cells to NSC73306 (50), the role of Ctr1 in resistance to thiosemicarbazones is unclear and needs further investigation.

Besides the changed intracellular drug levels (and the above-mentioned impact of RNA polymerase mutations in case of antiviral activity of some thiosemicarbazones), the cellular mechanisms of thiosemicarbazones resistance have not been investigated in depth. Considering the central role of RR in the anticancer activity of thiosemicarbazones, it is worth-mentioning that although overexpression of $\mathrm{hRRM} 2$ is a common resistance mechanism for clinically approved RR inhibitors like hydroxyurea or gemcitabine, multiple RR-overexpressing cell lines (e.g. HU-7-S7, L1210/ED1, L1210/ED2, KB-HU or KB-GEM) displayed only a trend towards drug resistance against MAIQ or diverse Triapine derivatives $(19,28,202)$. In some cases, even enhanced sensitivity of these cell lines to thiosemicarbazone treatment was observed (202). Overall, this indicates that the RR expression levels do not have a central role in the resistance against thiosemicarbazones. 


\section{Thiosemicarbazones with MDR-selective activity}

As already mentioned above, certain thiosemicarbazones (mainly isatin derivatives including NSC73306 but also Dp44mT) show increased, rather than decreased toxicity against ABCB1-expressing MDR cells $(51,65,86,118,139,164,165,175,176,182,194)$. This "MDR-selective" toxicity is shared by several other compounds which are able to chelate metal ions including some $8-\mathrm{HQ}$ or phen derivatives $(51,70,74,80,182)$. This paradoxical hypersensitivity (collateral sensitivity) of multidrug-resistant cells suggests that, in addition to limiting the efficacy of chemotherapy, $A B C B 1$ should be considered as a "double-edged sword", which may be turned against cancer cells. However, as for many aspects of the thiosemicarbazone compound class, the exact mode of MDR-selective toxicity is not understood.

Following the discovery of the lysosomal accumulation of the redox-active copper complex of Dp44mT (115), it was postulated that the increased toxicity against MDR cells is due to the function of lysosomal $A B C B 1$ (86). Whereas $A B C B 1$ usually resides in the plasma membrane, glucose modulation was found to specifically increase the lysosomal accumulation of $A B C B 1$ together with an increase of the sensitivity of MDR cells toward Dp44mT (164). A similar mechanism was postulated for related ligands including Ap44mT (the acetylpyridine analogue of PTSC) and DpC as well as their zinc complexes, following trans-metalation to the respective copper complexes $(174,194)$. The functionality of intracellular (lysosomal) ABCB1 could be demonstrated by increased lysosomotropic drug sequestration (194), which led to a model suggesting that in MDR cells Dp44mT is targeted to the lysosomes by $A B C B 1$ (86). Congruently with this hypothesis, Dp44mT did not prove to be selectively toxic to MDR cells expressing $A B C B 1$ in the plasma membrane, suggesting that sensitivity against Dp44mT is restricted to MDR cells with lysosomal ABCB1 (51). At present, the clinical relevance of lysosomal $A B C B 1$ remains to be verified. Given the complexity of the mode of action of Dp44mT (Table 3), additional molecular alterations restricted to particular cell models may be necessary for the paradoxical increase of its toxicity in MDR cells.

Several MDR-selective compounds with chelating moieties (including isatin-bthiosemicarbazones such as NSC73306) were identified possessing increased toxicity 
against MDR cells expressing $A B C B 1$ solely in the plasma membrane (51). These were identified by a pharmacogenomic approach, correlating gene expression and drug activity patterns recorded against 60 cancer cell lines of different tissue origin ( $\mathrm{NCl} 60$ Screen) $(118,153,169,176)$. In contrast to serendipitously found MDR-targeting compounds whose preferential toxicity is often limited to specific cells, the MDR-selective toxicity of compounds identified based on the pharmacogenomic approach is mediated by surfaceexpressed $A B C B 1(51,175,182)$. These reports support the notion that $A B C B 1$, which is considered to be an universal marker of drug resistance, should be interpreted as a trait that can be targeted by new drugs $(64,65,175)$.

Structure-activity relationships predicting chemical features responsible for susceptibility to transport (Triapine and Dp44mT) or ABCB1-mediated toxicity (NSC73306) are not entirely understood (139). While Dp44mT is relatively similar to Triapine, thiosemicarbazones identified by the correlative approach are isatin-6thiosemicarbazones, which chelate metal ions via an $(\mathrm{O}, \mathrm{N}, \mathrm{S})$ donor atom set and have a different substitution pattern at the terminal nitrogen atom $(64,65,182)$. For isatin- 6 thiosemicarbazones, a pharmacophore model was suggested $(64,65,176)$, identifying chemical features that fine-tune selective toxicity towards $A B C B 1$-expressing cells, as summarized in Figure 7. It has to be noted that the model shown in Figure 7 could not be validated in a more extended library of thiosemicarbazones (139), suggesting that the identified descriptors are unique for this compound class. The role of the ligands' redox activity or complex stability with biologically relevant metal ions in MDR-selective toxicity is not known, as stability data for iron complexes of isatin-6-thiosemicarbazones are not available. However, based on their coordination mode, a decreased iron-binding ability (especially diminished for iron(II)) could be expected for these ligands, as compared to the $\alpha-N$-pyridyl thiosemicarbazones. Although cells become more sensitive with the expression of $A B C B 1$ (but not ABCG2 (191)), the mechanism of toxicity does not rely on the direct interaction with the transporter (118).

Taken together, the mechanisms responsible for MDR-selective toxicity are unknown. Chelation seems to be a necessary, although not sufficient, prerequisite but the nature of the metal complexes formed and the elicited cellular alterations remain elusive (176). 
Although the exact mechanism remains to be discovered, the MDR-selective toxicity of thiosemicarbazones represents a robust modality for targeting MDR cancer and might represent a promising modality for the treatment of late stage patients after failure of therapy due to $A B C B 1$ expression.

\section{Conclusions}

In this review, we highlight and summarize the current knowledge on anticancer thiosemicarbazones with respect to their physico-chemical data with iron, interaction with the cellular iron homeostasis and resistance development. By this we wanted to emphasize that thiosemicarbazones are generally not "simple" chelators removing cellular iron but have to be considered as iron/metal-interacting drugs with a multi-facetted mode of action.

For the most prominent representative Triapine, despite multiple phase $\mathrm{I} / \mathrm{II}$ trials, clinical approval seems to be difficult. However, over the last few decades a great amount of additional knowledge has been gained on the biological activity of thiosemicarbazones in cell culture and in vivo. At least partially, these data have already been used to generate novel, improved compounds (two of them currently in clinical phase I trials), which hopefully will overcome the drawbacks of Triapine finally resulting in a thiosemicarbazone approved for cancer treatment. 


\section{References}

1. Altintop MD, Temel HE, Sever B, Akalin Ciftci G, Kaplancikli ZA. Synthesis and Evaluation of New Benzodioxole- Based Thiosemicarbazone Derivatives as Potential Antitumor Agents. Molecules 21, 2016.

2. Antholine WE, Taketa F. Effects of 2-formylpyridine monothiosemicarbazonato copper II on red cell components. J Inorg Biochem 20: 69-78, 1984.

3. Antolin AA, Workman P, Mestres J, Al-Lazikani B. Polypharmacology in Precision Oncology: Current Applications and Future Prospects. Curr Pharm Des, 2016.

4. Attia S, Kolesar J, Mahoney MR, Pitot HC, Laheru D, Heun J, Huang W, Eickhoff J, Erlichman C, Holen KD. A phase 2 consortium (P2C) trial of 3-aminopyridine-2carboxaldehyde thiosemicarbazone (3-AP) for advanced adenocarcinoma of the pancreas. Invest New Drugs 26: 369-79, 2008.

5. Aye $\mathrm{Y}$, Li M, Long MJ, Weiss RS. Ribonucleotide reductase and cancer: biological mechanisms and targeted therapies. Oncogene 34: 2011-21, 2015.

6. Aye $\mathrm{Y}$, Long MJ, Stubbe J. Mechanistic studies of semicarbazone triapine targeting human ribonucleotide reductase in vitro and in mammalian cells: tyrosyl radical quenching not involving reactive oxygen species. J Biol Chem 287: 35768-78, 2012.

7. Ba Q, Hao M, Huang H, Hou J, Ge S, Zhang Z, Yin J, Chu R, Jiang H, Wang F, Chen $K$, Liu H, Wang H. Iron deprivation suppresses hepatocellular carcinoma growth in experimental studies. Clin Cancer Res 17: 7625-33, 2011.

8. Bacher F, Dömötör O, Enyedy ÉA, Filipović L, Radulović S, Smith GS, Arion VB. Complex formation reactions of gallium (III) and iron (III/II) with I-prolinethiosemicarbazone hybrids: A comparative study. Inorganica Chimica Acta 455: 505513, 2017.

9. Baldwin GS. Phosphorylation of cyclin-dependent kinase 2 peptides enhances metal binding. Biochem Biophys Res Commun 379: 151-4, 2009.

10. Banerjee $U$, Cheng $X$. Exchange protein directly activated by cAMP encoded by the mammalian rapgef3 gene: Structure, function and therapeutics. Gene, 2015.

11. Basha MT, Bordini J, Richardson DR, Martinez M, Bernhardt PV. Kinetico- 
mechanistic studies on methemoglobin generation by biologically active thiosemicarbazone iron (III) complexes. Journal of inorganic biochemistry 162: 326333, 2016.

12. Basha MT, Rodríguez C, Richardson DR, Martínez M, Bernhardt PV. Kinetic studies on the oxidation of oxyhemoglobin by biologically active iron thiosemicarbazone complexes: relevance to iron-chelator-induced methemoglobinemia. J Biol Inorg Chem 19: 1-9, 2013.

13. Belardinelli JM, Morbidoni HR. Mutations in the essential FAS II beta-hydroxyacyl ACP dehydratase complex confer resistance to thiacetazone in Mycobacterium tuberculosis and Mycobacterium kansasii. Mol Microbiol 86: 568-79, 2012.

14. Bernhardt PV, Sharpe PC, Islam M, Lovejoy DB, Kalinowski DS, Richardson DR. Iron chelators of the dipyridylketone thiosemicarbazone class: precomplexation and transmetalation effects on anticancer activity. J Med Chem 52: 407-15, 2009.

15. Bock C, Lengauer T. Managing drug resistance in cancer: lessons from HIV therapy. Nat Rev Cancer 12: 494-501, 2012.

16. Bolognesi ML, Cavalli A. Multitarget Drug Discovery and Polypharmacology. ChemMedChem 11: 1190-2, 2016.

17. Byrnes RW, Mohan M, Antholine WE, Xu RX, Petering DH. Oxidative stress induced by a copper-thiosemicarbazone complex. Biochemistry 29: 7046-53, 1990.

18. Campos MC, Castro-Pinto DB, Ribeiro GA, Berredo-Pinho MM, Gomes LH, da Silva Bellieny MS, Goulart CM, Echevarria A, Leon LL. P-glycoprotein efflux pump plays an important role in Trypanosoma cruzi drug resistance. Parasitol Res 112: 2341-51, 2013.

19. Carter GL, Cory JG. Cross-resistance patterns in hydroxyurea-resistant leukemia L1210 cells. Cancer Res 48: 5796-9, 1988.

20. Castro EF, Campos RH, Cavallaro LV. Stability of the resistance to the thiosemicarbazone derived from 5,6-dimethoxy-1-indanone, a non-nucleoside polymerase inhibitor of bovine viral diarrhea virus. PLoS One 9: e100528, 2014.

21. Castro EF, Fabian LE, Caputto ME, Gagey D, Finkielsztein LM, Moltrasio GY, Moglioni AG, Campos RH, Cavallaro LV. Inhibition of bovine viral diarrhea virus RNA synthesis by thiosemicarbazone derived from 5,6-dimethoxy-1-indanone. J Virol 85: 5436-45, 
2011.

22. CF Jr B, Mesmer R. The hydrolysis of cations. John Wiley and Sons, New York; 1976.

23. Chaston TB, Lovejoy DB, Watts RN, Richardson DR. Examination of the antiproliferative activity of iron chelators: multiple cellular targets and the different mechanism of action of triapine compared with desferrioxamine and the potent pyridoxal isonicotinoyl hydrazone analogue 311. Clin Cancer Res 9: 402-14, 2003.

24. Chitambar CR. Gallium and its competing roles with iron in biological systems. Biochim Biophys Acta 1863: 2044-53, 2016.

25. Cho EC, Yen Y. Novel regulators and molecular mechanisms of p53R2 and its disease relevance. Biochimie 123: 81-4, 2016.

26. Choi BS, Alberti DB, Schelman WR, Kolesar JM, Thomas JP, Marnocha R, Eickhoff JC, Ivy SP, Wilding G, Holen KD. The maximum tolerated dose and biologic effects of 3aminopyridine-2-carboxaldehyde thiosemicarbazone (3-AP) in combination with irinotecan for patients with refractory solid tumors. Cancer Chemother Pharmacol 66: 973-80, 2010.

27. Chung LC, Tsui KH, Feng TH, Lee SL, Chang PL, Juang HH. L-Mimosine blocks cell proliferation via upregulation of B-cell translocation gene 2 and $\mathrm{N}$-myc downstream regulated gene 1 in prostate carcinoma cells. Am J Physiol Cell Physiol 302: C676-85, 2012.

28. Cory JG, Carter GL. Leukemia L1210 cell lines resistant to ribonucleotide reductase inhibitors. Cancer Res 48: 839-43, 1988.

29. Cory JG, Cory AH, Lorico A, Rappa G, Sartorelli AC. Altered efflux properties of mouse leukemia L1210 cells resistant to 4-methyl-5-amino-1-formylisoquinoline thiosemicarbazone. Anticancer Res 17: 3185-93, 1997.

30. Crenshaw TR, Cory JG. Overexpression of protein disulfide isomerase-like protein in a mouse leukemia L1210 cell line selected for resistance to 4-methyl-5-amino-1formylisoquinoline thiosemicarbazone, a ribonucleotide reductase inhibitor. $A d v$ Enzyme Regul 42: 143-57, 2002.

31. Cresawn SG, Prins C, Latner DR, Condit RC. Mapping and phenotypic analysis of spontaneous isatin-beta-thiosemicarbazone resistant mutants of vaccinia virus. 
Virology 363: 319-32, 2007.

32. Darnell G, Richardson DR. The potential of iron chelators of the pyridoxal isonicotinoyl hydrazone class as effective antiproliferative agents III: the effect of the ligands on molecular targets involved in proliferation. Blood 94: 781-92, 1999.

33. de Almeida SM, da Silva LP, de Lima LR, Longato GB, Padilha RJ, Alves LC, Brayner FA, Ruiz AL, de Carvalho JE, Beltrao El, de Lima MD, de Carvalho Junior LB. Ultrastructural Assessment of 2-(acridin-9-ylmethylene)-Nphenylhydrazinecarbothioamide activity on human breast adenocarcinoma cells. Micron 90: 114-122, 2016.

34. Dean M, Fojo T, Bates S. Tumour stem cells and drug resistance. Nat Rev Cancer 5: 275-84, 2005.

35. Debebe Z, Ammosova T, Breuer D, Lovejoy DB, Kalinowski DS, Kumar K, Jerebtsova M, Ray P, Kashanchi F, Gordeuk VR, Richardson DR, Nekhai S. Iron chelators of the di-2-pyridylketone thiosemicarbazone and 2-benzoylpyridine thiosemicarbazone series inhibit HIV-1 transcription: identification of novel cellular targets--iron, cyclindependent kinase (CDK) 2, and CDK9. Mol Pharmacol 79: 185-96, 2011.

36. Debebe Z, Ammosova T, Jerebtsova M, Kurantsin-Mills J, Niu X, Charles S, Richardson DR, Ray PE, Gordeuk VR, Nekhai S. Iron chelators ICL670 and 311 inhibit HIV-1 transcription. Virology 367: 324-33, 2007.

37. DeConti RC, Toftness BR, Agrawal KC, Tomchick R, Mead JA, Bertino JR, Sartorelli AC, Creasey WA. Clinical and pharmacological studies with 5-hydroxy-2-formylpyridine thiosemicarbazone. Cancer Res 32: 1455-62, 1972.

38. Deeken JF, Robey RW, Shukla S, Steadman K, Chakraborty AR, Poonkuzhali B, Schuetz EG, Holbeck S, Ambudkar SV, Bates SE. Identification of compounds that correlate with $A B C G 2$ transporter function in the National Cancer Institute Anticancer Drug Screen. Mol Pharmacol 76: 946-56, 2009.

39. Dömötör O, May NV, Pelivan K, Kiss T, Keppler BK, Kowol CR, Enyedy ÉA. A comparative study of $\alpha-\mathrm{N}$-pyridyl thiosemicarbazones: spectroscopic properties, solution stability and copper (II) complexation. Inorganica Chimica Acta: doi.org/10.1016/j.ica.2017.07.001, 2017.

40. Donald PR, Mcllleron H. Chapter 59 - Antituberculosis drugs. In: Tuberculosis. 
Edinburgh: W.B. Saunders; 2009. pp. 608-617.

41. Dosumu EA. Pattern of some haematological indices in newly diagnosed pulmonary tuberculosis cases in Iwo, Nigeria: diagnostic and therapeutic implications. Niger J Med 10: 18-20, 2001.

42. Easmon J, Heinisch G, Holzer W, Rosenwirth B. Pyridazines. 63. Novel thiosemicarbazones derived from formyl-and acyldiazines: synthesis, effects on cell proliferation, and synergism with antiviral agents. Journal of medicinal chemistry 35: 3288-3296, 1992.

43. Enyedy EA, Nagy NV, Zsigo E, Kowol CR, Arion VB, Keppler BK, Kiss T. Comparative Solution Equilibrium Study of the Interactions of Copper(II), Iron(II) and Zinc(II) with Triapine (3-Aminopyridine-2-carbaldehyde Thiosemicarbazone) and Related Ligands. Eur J Inorg Chem: 1717-1728, 2010.

44. Enyedy EA, Primik MF, Kowol CR, Arion VB, Kiss T, Keppler BK. Interaction of Triapine and related thiosemicarbazones with iron(III)/(II) and gallium(III): a comparative solution equilibrium study. Dalton Trans 40: 5895-905, 2011.

45. Enyedy EA, Zsigo E, Nagy NV, Kowol CR, Roller A, Keppler BK, Kiss T. ComplexFormation Ability of Salicylaldehyde Thiosemicarbazone towards ZnII, Cull, Fell, FellI and Galll lons. European Journal of Inorganic Chemistry: 4036-4047, 2012.

46. Farkas E, Enyedy ÉA, Zékány L, Deák G. Interaction between iron (II) and hydroxamic acids: oxidation of iron (II) to iron (III) by desferrioxamine B under anaerobic conditions. Journal of inorganic biochemistry 83: 107-114, 2001.

47. Feun L, Modiano M, Lee K, Mao J, Marini A, Savaraj N, Plezia P, Almassian B, Colacino E, Fischer J, MacDonald S. Phase I and pharmacokinetic study of 3aminopyridine-2-carboxaldehyde thiosemicarbazone (3-AP) using a single intravenous dose schedule. Cancer Chemother Pharmacol 50: 223-9, 2002.

48. Fojo T. Commentary: Novel therapies for cancer: why dirty might be better. Oncologist 13: 277-83, 2008.

49. Fojo T, Bates S. Strategies for reversing drug resistance. Oncogene 22: 7512-23, 2003.

50. Fung KL, Tepede AK, Pluchino KM, Pouliot LM, Pixley JN, Hall MD, Gottesman MM. Uptake of Compounds That Selectively Kill Multidrug-Resistant Cells: The Copper 
Transporter SLC31A1 (CTR1) Increases Cellular Accumulation of the Thiosemicarbazone NSC73306. Molecular Pharmaceutics 11: 2692-2702, 2014.

51. Furedi A, Toth S, Szebenyi K, Pape VF, Turk D, Kucsma N, Cervenak L, Tovari J, Szakacs G. Identification and Validation of Compounds Selectively Killing Resistant Cancer: Delineating Cell Line-Specific Effects from P-Glycoprotein-Induced Toxicity. Mol Cancer Ther 16: 45-56, 2017.

52. Gaal A, Orgovan G, Polgari Z, Reti A, Mihucz VG, Bosze S, Szoboszlai N, Streli C. Complex forming competition and in-vitro toxicity studies on the applicability of di2-pyridylketone-4,4,-dimethyl-3-thiosemicarbazone (Dp44mT) as a metal chelator. J Inorg Biochem 130: 52-8, 2014.

53. Gaál A, Orgován G, Polgári Z, Réti A, Mihucz VG, Bősze S, Szoboszlai N, Streli C. Complex forming competition and in-vitro toxicity studies on the applicability of di2-pyridylketone-4, 4,-dimethyl-3-thiosemicarbazone (Dp44mT) as a metal chelator. Journal of Inorganic Biochemistry 130: 52-58, 2014.

54. Galanski M, Zimmermann W, Berger M, Baumgartner C, Giester G, Keppler BK. Carboxylation of 2-hydroxyethyl-substituted tetrachloro(ethane-1,2-diamine)platinum(IV) complexes - A new synthetic approach to anticancer platinum compounds. European Journal of Inorganic Chemistry: 417-421, 2002.

55. Garraway LA, Janne PA. Circumventing cancer drug resistance in the era of personalized medicine. Cancer Discov 2: 214-26, 2012.

56. Giles FJ, Fracasso PM, Kantarjian HM, Cortes JE, Brown RA, Verstovsek S, Alvarado Y, Thomas DA, Faderl S, Garcia-Manero G, Wright LP, Samson T, Cahill A, Lambert P, Plunkett W, Sznol M, DiPersio JF, Gandhi V. Phase I and pharmacodynamic study of Triapine, a novel ribonucleotide reductase inhibitor, in patients with advanced leukemia. Leuk Res 27: 1077-83, 2003.

57. Gottesman MM, Fojo T, Bates SE. Multidrug resistance in cancer: role of ATPdependent transporters. Nat Rev Cancer 2: 48-58, 2002.

58. Gottesman MM, Ludwig J, Xia D, Szakacs G. Defeating drug resistance in cancer. Discov Med 6: 18-23, 2006.

59. Green DA, Antholine WE, Wong SJ, Richardson DR, Chitambar CR. Inhibition of malignant cell growth by 311 , a novel iron chelator of the pyridoxal isonicotinoyl 
hydrazone class: effect on the R2 subunit of ribonucleotide reductase. Clin Cancer Res 7: 3574-9, 2001.

60. Guarino E, Salguero I, Kearsey SE. Cellular regulation of ribonucleotide reductase in eukaryotes. Semin Cell Dev Biol 30: 97-103, 2014.

61. Guo ZL, Richardson DR, Kalinowski DS, Kovacevic Z, Tan-Un KC, Chan GC. The novel thiosemicarbazone, di-2-pyridylketone 4-cyclohexyl-4-methyl-3-thiosemicarbazone $(\mathrm{DpC})$, inhibits neuroblastoma growth in vitro and in vivo via multiple mechanisms. J Hematol Oncol 9: 98, 2016.

62. Gutierrez EM, Seebacher NA, Arzuman L, Kovacevic Z, Lane DJ, Richardson V, Merlot AM, Lok H, Kalinowski DS, Sahni S, Jansson PJ, Richardson DR. Lysosomal membrane stability plays a major role in the cytotoxic activity of the anti-proliferative agent, di2-pyridylketone 4,4-dimethyl-3-thiosemicarbazone (Dp44mT). Biochim Biophys Acta 1863: 1665-81, 2016.

63. Hall IH, Miller MC, West DX. Antineoplastic and Cytotoxic Activities of Nickel(II) Complexes of Thiosemicarbazones. Met Based Drugs 4: 89-95, 1997.

64. Hall MD, Brimacombe KR, Varonka MS, Pluchino KM, Monda JK, Li J, Walsh MJ, Boxer MB, Warren TH, Fales HM, Gottesman MM. Synthesis and structure-activity evaluation of isatin-beta-thiosemicarbazones with improved selective activity toward multidrug-resistant cells expressing P-glycoprotein. J Med Chem 54: 587889, 2011.

65. Hall MD, Salam NK, Hellawell JL, Fales HM, Kensler CB, Ludwig JA, Szakacs G, Hibbs $D E$, Gottesman MM. Synthesis, activity, and pharmacophore development for isatin-beta-thiosemicarbazones with selective activity toward multidrug-resistant cells. J Med Chem 52: 3191-204, 2009.

66. Halliwell B, Gutteridge JM. Free radicals in biology and medicine: Oxford University Press, USA; 2010.

67. Hanahan D, Weinberg RA. The hallmarks of cancer. Cell 100: 57-70, 2000.

68. Hanahan D, Weinberg RA. Hallmarks of cancer: the next generation. Cell 144: 64674, 2011.

69. Harris DC, Aisen P. Facilitation of Fe (II) antoxidation by Fe (III) complexing agents. Biochimica et Biophysica Acta (BBA)-General Subjects 329: 156-158, 1973. 
70. Heffeter P, Jakupec MA, Korner W, Chiba P, Pirker C, Dornetshuber R, Elbling L, Sutterluty H, Micksche M, Keppler BK, Berger W. Multidrug-resistant cancer cells are preferential targets of the new antineoplastic lanthanum compound KP772 (FFC24). Biochem Pharmacol 73: 1873-86, 2007.

71. Heffeter P, Jakupec MA, Korner W, Wild S, von Keyserlingk NG, Elbling L, Zorbas H, Korynevska A, Knasmuller S, Sutterluty H, Micksche M, Keppler BK, Berger W. Anticancer activity of the lanthanum compound [tris(1,10phenanthroline)lanthanum(III)]trithiocyanate (KP772; FFC24). Biochem Pharmacol 71: 426-40, 2006.

72. Heffeter $P$, Jungwirth $U$, Jakupec $M$, Hartinger $C$, Galanski $M$, Elbling L, Micksche $M$, Keppler B, Berger W. Resistance against novel anticancer metal compounds: differences and similarities. Drug Resist Updat 11: 1-16, 2008.

73. Heffeter P, Pirker C, Kowol CR, Herrman G, Dornetshuber R, Miklos W, Jungwirth U, Koellensperger G, Keppler BK, Berger W. Impact of terminal dimethylation on the resistance profile of alpha-N-heterocyclic thiosemicarbazones. Biochem Pharmacol 83: 1623-33, 2012.

74. Heffeter P, Popovic-Bijelic A, Saiko P, Dornetshuber R, Jungwirth U, Voevodskaya N, Biglino D, Jakupec MA, Elbling L, Micksche M, Szekeres T, Keppler BK, Graslund A, Berger W. Ribonucleotide reductase as one important target of [Tris(1,10phenanthroline)lanthanum(III)] trithiocyanate (KP772). Curr Cancer Drug Targets 9: 595-607, 2009.

75. Heinz U, Hegetschweiler K, Acklin P, Faller B, Lattmann R, Schnebli HP. 4-[3, 5-Bis (2hydroxyphenyl)-1, 2, 4-triazol-1-yl]-benzoic Acid: A Novel Efficient and Selective Iron (III) Complexing Agent. Angewandte Chemie International Edition 38: 2568-2570, 1999.

76. Hider R. Recent developments centered on orally active iron chelators. Thalassemia reports 4, 2014.

77. Hider RC, Liu ZD. Emerging understanding of the advantage of small molecules such as hydroxypyridinones in the treatment of iron overload. Current medicinal chemistry 10: 1051-1064, 2003.

78. Hientz K, Mohr A, Bhakta-Guha D, Efferth T. The role of p53 in cancer drug 
resistance and targeted chemotherapy. Oncotarget 8: 8921-8946, 2017.

79. Huang $\mathrm{H}$, Chen $\mathrm{Q}$, Ku X, Meng L, Lin L, Wang X, Zhu C, Wang Y, Chen Z, Li M, Jiang H, Chen K, Ding J, Liu H. A series of alpha-heterocyclic carboxaldehyde thiosemicarbazones inhibit topoisomerase Ilalpha catalytic activity. J Med Chem 53: 3048-64, 2010.

80. Huang Y, Blower PE, Yang C, Barbacioru C, Dai Z, Zhang Y, Xiao JJ, Chan KK, Sadee W. Correlating gene expression with chemical scaffolds of cytotoxic agents: ellipticines as substrates and inhibitors of MDR1. Pharmacogenomics J 5: 112-25, 2005.

81. Hwang J, Kim HS, Kang BS, Kim DH, Ryoo ZY, Choi SU, Lee S. RGS19 converts iron deprivation stress into a growth-inhibitory signal. Biochem Biophys Res Commun 464: 168-75, 2015.

82. Iommarini L, Ghelli A, Gasparre G, Porcelli AM. Mitochondrial metabolism and energy sensing in tumor progression. Biochim Biophys Acta 1858: 582-590, 2017.

83. Ishiguro K, Lin ZP, Penketh PG, Shyam K, Zhu R, Baumann RP, Zhu YL, Sartorelli AC, Rutherford TJ, Ratner ES. Distinct mechanisms of cell-kill by triapine and its terminally dimethylated derivative Dp44mT due to a loss or gain of activity of their copper(II) complexes. Biochem Pharmacol 91: 312-22, 2014.

84. Jansson PJ, Kalinowski DS, Lane DJ, Kovacevic Z, Seebacher NA, Fouani L, Sahni S, Merlot AM, Richardson DR. The renaissance of polypharmacology in the development of anti-cancer therapeutics: Inhibition of the "Triad of Death" in cancer by Di-2-pyridylketone thiosemicarbazones. Pharmacol Res 100: 255-60, 2015.

85. Jansson PJ, Sharpe PC, Bernhardt PV, Richardson DR. Novel thiosemicarbazones of the ApT and DpT series and their copper complexes: identification of pronounced redox activity and characterization of their antitumor activity. J Med Chem 53: 5759-69, 2010.

86. Jansson PJ, Yamagishi T, Arvind A, Seebacher N, Gutierrez E, Stacy A, Maleki S, Sharp D, Sahni S, Richardson DR. Di-2-pyridylketone 4,4-dimethyl-3-thiosemicarbazone (Dp44mT) overcomes multidrug resistance by a novel mechanism involving the hijacking of lysosomal P-glycoprotein (Pgp). J Biol Chem 290: 9588-603, 2015.

87. Jungwirth U, Kowol CR, Keppler BK, Hartinger CG, Berger W, Heffeter P. Anticancer 
activity of metal complexes: involvement of redox processes. Antioxid Redox Signal 15: 1085-127, 2011.

88. Kachalaki S, Ebrahimi M, Mohamed Khosroshahi L, Mohammadinejad S, Baradaran B. Cancer chemoresistance; biochemical and molecular aspects: a brief overview. Eur J Pharm Sci 89: 20-30, 2016.

89. Kalinowski DS, Richardson DR. Future of toxicology--iron chelators and differing modes of action and toxicity: the changing face of iron chelation therapy. Chem Res Toxicol 20: 715-20, 2007.

90. Kalinowski DS, Stefani C, Toyokuni S, Ganz T, Anderson GJ, Subramaniam NV, Trinder D, Olynyk JK, Chua A, Jansson PJ, Sahni S, Lane DJ, Merlot AM, Kovacevic Z, Huang ML, Lee CS, Richardson DR. Redox cycling metals: Pedaling their roles in metabolism and their use in the development of novel therapeutics. Biochim Biophys Acta 1863: 727-48, 2016.

91. Karp JE, Giles FJ, Gojo I, Morris L, Greer J, Johnson B, Thein M, Sznol M, Low J. A phase I study of the novel ribonucleotide reductase inhibitor 3-aminopyridine-2carboxaldehyde thiosemicarbazone (3-AP, Triapine) in combination with the nucleoside analog fludarabine for patients with refractory acute leukemias and aggressive myeloproliferative disorders. Leuk Res 32: 71-7, 2008.

92. Khamisipour G, Jadidi-Niaragh F, Jahromi AS, Zandi K, Hojjat-Farsangi M. Mechanisms of tumor cell resistance to the current targeted-therapy agents. Tumour Biol 37: 10021-39, 2016.

93. Kidane TZ, Farhad R, Lee KJ, Santos A, Russo E, Linder MC. Uptake of copper from plasma proteins in cells where expression of CTR1 has been modulated. Biometals 25: 697-709, 2012.

94. Kolesar J, Brundage RC, Pomplun M, Alberti D, Holen K, Traynor A, Ivy P, Wilding G. Population pharmacokinetics of 3-aminopyridine-2-carboxaldehyde thiosemicarbazone (Triapine(R)) in cancer patients. Cancer Chemother Pharmacol 67: 393-400, 2011.

95. Kolesar JM, Sachidanandam K, Schelman WR, Eickhoff J, Holen KD, Traynor AM, Alberti DB, Thomas JP, Chitambar CR, Wilding G, Antholine WE. Cytotoxic Evaluation of 3-Aminopyridine-2-Carboxaldehyde Thiosemicarbazone, 3-AP, in Peripheral 
Blood Lymphocytes of Patients with Refractory Solid Tumors using Electron Paramagnetic Resonance. Exp Ther Med 2: 119-123, 2011.

96. Kolesar JM, Schelman WR, Geiger PG, Holen KD, Traynor AM, Alberti DB, Thomas JP, Chitambar CR, Wilding G, Antholine WE. Electron paramagnetic resonance study of peripheral blood mononuclear cells from patients with refractory solid tumors treated with Triapine. J Inorg Biochem 102: 693-8, 2008.

97. Kovacevic Z, Chikhani S, Lovejoy DB, Richardson DR. Novel thiosemicarbazone iron chelators induce up-regulation and phosphorylation of the metastasis suppressor $\mathrm{N}$-myc down-stream regulated gene 1: a new strategy for the treatment of pancreatic cancer. Mol Pharmacol 80: 598-609, 2011.

98. Kovacevic Z, Menezes SV, Sahni S, Kalinowski DS, Bae DH, Lane DJ, Richardson DR. The Metastasis Suppressor, N-MYC Downstream-regulated Gene-1 (NDRG1), Downregulates the ErbB Family of Receptors to Inhibit Downstream Oncogenic Signaling Pathways. J Biol Chem 291: 1029-52, 2016.

99. Kowol CR, Berger R, Eichinger R, Roller A, Jakupec MA, Schmidt PP, Arion VB, Keppler BK. Gallium(III) and Iron(III) Complexes of alpha -N-Heterocyclic Thiosemicarbazones: Synthesis, Characterization, Cytotoxicity, and Interaction with Ribonucleotide Reductase. J. Med. Chem. 50: 1254-1265, 2007.

100. Kowol CR, Heffeter P, Miklos W, Gille L, Trondl R, Cappellacci L, Berger W, Keppler BK. Mechanisms underlying reductant-induced reactive oxygen species formation by anticancer copper(II) compounds. J Biol Inorg Chem 17: 409-23, 2012.

101. Kowol CR, Miklos W, Pfaff S, Hager S, Kallus S, Pelivan K, Kubanik M, Enyedy EA, Berger W, Heffeter P, Keppler BK. Impact of Stepwise NH2-Methylation of Triapine on the Physicochemical Properties, Anticancer Activity, and Resistance Circumvention. J Med Chem 59: 6739-52, 2016.

102. Kowol CR, Trondl R, Heffeter P, Arion VB, Jakupec MA, Roller A, Galanski M, Berger W, Keppler BK. Impact of Metal Coordination on Cytotoxicity of 3-Aminopyridine-2carboxaldehyde Thiosemicarbazone (Triapine) and Novel Insights into Terminal Dimethylation. Journal of Medicinal Chemistry 52: 5032-5043, 2009.

103. Krakoff IH, Etcubanas E, Tan C, Mayer K, Bethune V, Burchenal JH. Clinical trial of 5hydroxypicolinaldehyde thiosemicarbazone (5-HP; NSC-107392), with special 
reference to its iron-chelating properties. Cancer Chemother Rep 58: 207-12, 1974.

104. Krishan S, Richardson DR, Sahni S. The Anticancer Agent, Di-2-Pyridylketone 4,4Dimethyl-3-Thiosemicarbazone (Dp44mT), Up-Regulates the AMPK-Dependent Energy Homeostasis Pathway in Cancer Cells. Biochim Biophys Acta 1863: 29162933, 2016.

105. Kulp KS, Green SL, Vulliet PR. Iron deprivation inhibits cyclin-dependent kinase activity and decreases cyclin D/CDK4 protein levels in asynchronous MDA-MB-453 human breast cancer cells. Exp Cell Res 229: 60-8, 1996.

106. Kunos CA, Chu E, Beumer JH, Sznol M, Ivy SP. Phase I trial of daily triapine in combination with cisplatin chemotherapy for advanced-stage malignancies. Cancer Chemother Pharmacol 79: 201-207, 2017.

107. Kunos CA, Radivoyevitch T, Ingalls ST, Hoppel CL. Management of 3-aminopyridine2-carboxaldehyde thiosemicarbazone-induced methemoglobinemia. Future Oncol 8: 145-50, 2012.

108. Kunos CA, Radivoyevitch T, Pink J, Chiu SM, Stefan T, Jacobberger J, Kinsella TJ. Ribonucleotide reductase inhibition enhances chemoradiosensitivity of human cervical cancers. Radiat Res 174: 574-81, 2010.

109. Kunos CA, Waggoner S, von Gruenigen V, Eldermire E, Pink J, Dowlati A, Kinsella TJ. Phase I trial of pelvic radiation, weekly cisplatin, and 3-aminopyridine-2carboxaldehyde thiosemicarbazone (3-AP, NSC \#663249) for locally advanced cervical cancer. Clin Cancer Res 16: 1298-306, 2010.

110. Lee JC, Chiang KC, Feng TH, Chen YJ, Chuang ST, Tsui KH, Chung LC, Juang HH. The Iron Chelator, Dp44mT, Effectively Inhibits Human Oral Squamous Cell Carcinoma Cell Growth in Vitro and in Vivo. Int J Mol Sci 17, 2016.

111. Li P, Zheng X, Shou K, Niu Y, Jian C, Zhao Y, Yi W, Hu X, Yu A. The iron chelator Dp44mT suppresses osteosarcoma's proliferation, invasion and migration: in vitro and in vivo. Am J Transl Res 8: 5370-5385, 2016.

112. Liang SX, Richardson DR. The effect of potent iron chelators on the regulation of p53: examination of the expression, localization and DNA-binding activity of p53 and the transactivation of WAF1. Carcinogenesis 24: 1601-14, 2003.

113. Lide D. Handbook of Chemistry and Physics, 86th edn. CRC. Taylor \& Francis; 2005. 
pp. 8-21.

114. Liu W, Xing F, liizumi-Gairani M, Okuda H, Watabe M, Pai SK, Pandey PR, Hirota S, Kobayashi A, Mo YY, Fukuda K, Li Y, Watabe K. N-myc downstream regulated gene 1 modulates Wnt-beta-catenin signalling and pleiotropically suppresses metastasis. EMBO Mol Med 4: 93-108, 2012.

115. Lovejoy DB, Jansson PJ, Brunk UT, Wong J, Ponka P, Richardson DR. Antitumor activity of metal-chelating compound $\mathrm{Dp} 44 \mathrm{mT}$ is mediated by formation of a redoxactive copper complex that accumulates in lysosomes. Cancer Res 71: 5871-80, 2011.

116. Lovejoy DB, Sharp DM, Seebacher N, Obeidy P, Prichard T, Stefani C, Basha MT, Sharpe PC, Jansson PJ, Kalinowski DS, Bernhardt PV, Richardson DR. Novel secondgeneration di-2-pyridylketone thiosemicarbazones show synergism with standard chemotherapeutics and demonstrate potent activity against lung cancer xenografts after oral and intravenous administration in vivo. J Med Chem 55: 7230-44, 2012.

117. Lu J, Guo H, Zeng X, Zhang Y, Zhao P, Jiang J, Zang L. Synthesis and characterization of unsymmetrical oxidovanadium complexes: DNA-binding, cleavage studies and antitumor activities. Journal of inorganic biochemistry 112: 39-48, 2012.

118. Ludwig JA, Szakacs G, Martin SE, Chu BF, Cardarelli C, Sauna ZE, Caplen NJ, Fales HM, Ambudkar SV, Weinstein JN, Gottesman MM. Selective toxicity of NSC73306 in MDR1-positive cells as a new strategy to circumvent multidrug resistance in cancer. Cancer Res 66: 4808-15, 2006.

119. Lui GY, Kovacevic Z, S VM, Kalinowski DS, Merlot AM, Sahni S, Richardson DR. Novel thiosemicarbazones regulate the signal transducer and activator of transcription 3 (STAT3) pathway: inhibition of constitutive and interleukin 6-induced activation by iron depletion. Mol Pharmacol 87: 543-60, 2015.

120. Lui GY, Obeidy P, Ford SJ, Tselepis C, Sharp DM, Jansson PJ, Kalinowski DS, Kovacevic Z, Lovejoy DB, Richardson DR. The iron chelator, deferasirox, as a novel strategy for cancer treatment: oral activity against human lung tumor xenografts and molecular mechanism of action. Mol Pharmacol 83: 179-90, 2013.

121. Massimi M, Cardarelli S, Galli F, Giardi MF, Ragusa F, Panera N, Cinque B, Cifone MG, 
Biagioni S, Giorgi M. Increase of Intracellular Cyclic AMP by PDE4 Inhibitors Affects HepG2 Cell Cycle Progression and Survival. J Cell Biochem 118: 1401-1411, 2017.

122. McBryde W. A Critical Review of Equilibrium Data for Proton-and Metal Complexes of 1, 10-Phenanthroline, 2, 2'-Bipyridyl and Related Compounds: Critical Evaluation of Equilibrium Constants in Solution: Stability Constants of Metal Complexes: Elsevier; 1978. 1-17 p.

123. Merkofer M, Kissner R, Hider RC, Koppenol WH. Redox properties of the iron complexes of orally active iron chelators CP20, CP502, CP509, and ICL670. Helvetica chimica acta 87: 3021-3034, 2004.

124. Merlot AM, Sahni S, Lane DJ, Fordham AM, Pantarat N, Hibbs DE, Richardson V, Doddareddy MR, Ong JA, Huang ML, Richardson DR, Kalinowski DS. Potentiating the cellular targeting and anti-tumor activity of Dp44mT via binding to human serum albumin: two saturable mechanisms of Dp44mT uptake by cells. Oncotarget 6: 10374-98, 2015.

125. Merlot AM, Shafie NH, Yu Y, Richardson V, Jansson PJ, Sahni S, Lane DJ, Kovacevic Z, Kalinowski DS, Richardson DR. Mechanism of the induction of endoplasmic reticulum stress by the anti-cancer agent, di-2-pyridylketone 4,4-dimethyl-3thiosemicarbazone (Dp44mT): Activation of PERK/elF2alpha, IRE1alpha, ATF6 and calmodulin kinase. Biochem Pharmacol 109: 27-47, 2016.

126. Miklos W, Heffeter P, Pirker C, Hager S, Kowol CR, Schoonhoven SV, Stojanovic M, Keppler BK, Berger W. Loss of phosphodiesterase 4D mediates acquired triapine resistance via Epac-Rap1-Integrin signaling. Oncotarget, 2016.

127. Miklos W, Pelivan K, Kowol CR, Pirker C, Dornetshuber-Fleiss R, Spitzwieser M, Englinger B, van Schoonhoven S, Cichna-Markl M, Koellensperger G, Keppler BK, Berger W, Heffeter P. Triapine-mediated ABCB1 induction via PKC induces widespread therapy unresponsiveness but is not underlying acquired triapine resistance. Cancer Lett 361: 112-20, 2015.

128. Milunovic MN, Enyedy EvA, Nagy NrV, Kiss Ts, Trondl R, Jakupec MA, Keppler BK, Krachler R, Novitchi G, Arion VB. L-and D-proline thiosemicarbazone conjugates: coordination behavior in solution and the effect of copper (II) coordination on their antiproliferative activity. Inorganic chemistry 51: 9309-9321, 2012. 
129. Moorthy NS, Cerqueira NM, Ramos MJ, Fernandes PA. Development of ribonucleotide reductase inhibitors: a review on structure activity relationships. Mini Rev Med Chem 13: 1862-72, 2013.

130. Motekaitis RJ, Martell AE. Stabilities of the iron (III) chelates of 1, 2-dimethyl-3hydroxy-4-pyridinone and related ligands. Inorganica chimica acta 183: 71-80, 1991.

131. Moussa RS, Kovacevic Z, Richardson DR. Differential targeting of the cyclindependent kinase inhibitor, p21CIP1/WAF1, by chelators with anti-proliferative activity in a range of tumor cell-types. Oncotarget 6: 29694-711, 2015.

132. Murren J, Modiano M, Clairmont C, Lambert P, Savaraj N, Doyle T, Sznol M. Phase I and pharmacokinetic study of triapine, a potent ribonucleotide reductase inhibitor, administered daily for five days in patients with advanced solid tumors. Clin Cancer Res 9: 4092-100, 2003.

133. Myers CR. Enhanced targeting of mitochondrial peroxide defense by the combined use of thiosemicarbazones and inhibitors of thioredoxin reductase. Free Radic Biol Med 91: 81-92, 2016.

134. Myers JM, Antholine WE, Zielonka J, Myers CR. The iron-chelating drug triapine causes pronounced mitochondrial thiol redox stress. Toxicol Lett 201: 130-6, 2011.

135. Narasimhan J, Antholine WE, Chitambar CR, Petering DH. Inhibition of iron uptake in $\mathrm{HL60}$ cells by 2-formylpyridine monothiosemicarbazonato $\mathrm{Cu}(\mathrm{II})$. Arch Biochem Biophys 289: 393-8, 1991.

136. Nurtjahja-Tjendraputra E, Fu D, Phang JM, Richardson DR. Iron chelation regulates cyclin D1 expression via the proteasome: a link to iron deficiency-mediated growth suppression. Blood 109: 4045-54, 2007.

137. Odenike OM, Larson RA, Gajria D, Dolan ME, Delaney SM, Karrison TG, Ratain MJ, Stock W. Phase I study of the ribonucleotide reductase inhibitor 3-aminopyridine-2carboxaldehyde-thiosemicarbazone (3-AP) in combination with high dose cytarabine in patients with advanced myeloid leukemia. Invest New Drugs 26: 2339, 2008.

138. Pai CC, Kearsey SE. A Critical Balance: dNTPs and the Maintenance of Genome Stability. Genes (Basel) 8, 2017. 
139. Pape VF, Toth S, Furedi A, Szebenyi K, Lovrics A, Szabo P, Wiese M, Szakacs G. Design, synthesis and biological evaluation of thiosemicarbazones, hydrazinobenzothiazoles and arylhydrazones as anticancer agents with a potential to overcome multidrug resistance. Eur J Med Chem 117: 335-54, 2016.

140. Pavan FR, Maia PID, Leite SRA, Deflon VM, Batista AA, Sato DN, Franzblau SG, Leite CQF. Thiosemicarbazones, semicarbazones, dithiocarbazates and hydrazide/hydrazones: Anti-Mycobacterium tuberculosis activity and cytotoxicity. European Journal of Medicinal Chemistry 45: 1898-1905, 2010.

141. Pearson RG. Hard and Soft Acids and Bases. Journal of the American Chemical Society 85: 3533-3539, 1963.

142. Pelivan K, Frensemeier L, Karst U, Koellensperger G, Bielec B, Hager S, Heffeter P, Keppler BK, Kowol CR. Understanding the metabolism of the anticancer drug Triapine: electrochemical oxidation, microsomal incubations and in vivo analysis using LC-HRMS. Analyst: 10.1039/C7AN00902J, 2017.

143. Pelivan K, Miklos W, van Schoonhoven S, Koellensperger G, Gille L, Berger W, Heffeter P, Kowol CR, Keppler BK. Differences in protein binding and excretion of Triapine and its Fe(III) complex. J Inorg Biochem, 2015.

144. Pessoto FS, Yokomizo CH, Prieto T, Fernandes CS, Silva AP, Kaiser CR, Basso EA, Nantes IL. Thiosemicarbazone p-Substituted Acetophenone Derivatives Promote the Loss of Mitochondrial Deltapsi, GSH Depletion, and Death in K562 Cells. Oxid Med Cell Longev 2015: 394367, 2015.

145. Pestell RG. New roles of cyclin D1. Am J Pathol 183: 3-9, 2013.

146. Popovic-Bijelic A, Kowol CR, Lind ME, Luo J, Himo F, Enyedy EA, Arion VB, Graslund A. Ribonucleotide reductase inhibition by metal complexes of Triapine (3aminopyridine-2-carboxaldehyde thiosemicarbazone): a combined experimental and theoretical study. J Inorg Biochem 105: 1422-31, 2011.

147. Potuckova E, Roh J, Machacek M, Sahni S, Stariat J, Sestak V, Jansova H, Haskova P, Jirkovska A, Vavrova K, Kovarikova P, Kalinowski DS, Richardson DR, Simunek T. In Vitro Characterization of the Pharmacological Properties of the Anti-Cancer Chelator, Bp4eT, and Its Phase I Metabolites. PLoS One 10: e0139929, 2015.

148. Prabhakaran R, Kalaivani P, Poornima P, Dallemer F, Huang R, Padma VV, Natarajan 
K. Synthesis, DNA/protein binding and in vitro cytotoxic studies of new palladium metallothiosemicarbazones. Bioorganic \& medicinal chemistry 21: 6742-6752, 2013.

149. Prins C, Cresawn SG, Condit RC. An isatin-beta-thiosemicarbazone-resistant vaccinia virus containing a mutation in the second largest subunit of the viral RNA polymerase is defective in transcription elongation. J Biol Chem 279: 44858-71, 2004.

150. Quach P, Gutierrez E, Basha MT, Kalinowski DS, Sharpe PC, Lovejoy DB, Bernhardt PV, Jansson PJ, Richardson DR. Methemoglobin formation by triapine, di-2pyridylketone-4, 4-dimethyl-3-thiosemicarbazone (Dp44mT), and other anticancer thiosemicarbazones: identification of novel thiosemicarbazones and therapeutics that prevent this effect. Molecular pharmacology 82: 105-114, 2012.

151. Rao VA, Klein SR, Agama KK, Toyoda E, Adachi N, Pommier Y, Shacter EB. The iron chelator Dp44mT causes DNA damage and selective inhibition of topoisomerase Ilalpha in breast cancer cells. Cancer Res 69: 948-57, 2009.

152. Rappa G, Lorico A, Liu MC, Kruh GD, Cory AH, Cory JG, Sartorelli AC. Overexpression of the multidrug resistance genes mdr1, mdr3, and mrp in L1210 leukemia cells resistant to inhibitors of ribonucleotide reductase. Biochem Pharmacol 54: 649-55, 1997.

153. Reinhold WC, Sunshine M, Liu H, Varma S, Kohn KW, Morris J, Doroshow J, Pommier Y. CellMiner: a web-based suite of genomic and pharmacologic tools to explore transcript and drug patterns in the NCl-60 cell line set. Cancer Res 72: 3499-511, 2012.

154. Richardson DR. Iron chelators as therapeutic agents for the treatment of cancer. Critical Reviews in Oncology Hematology 42: 267-281, 2002.

155. Richardson DR, Sharpe PC, Lovejoy DB, Senaratne D, Kalinowski DS, Islam M, Bernhardt PV. Dipyridyl Thiosemicarbazone Chelators with Potent and Selective Antitumor Activity Form Iron Complexes with Redox Activity. J. Med. Chem. 49: 6510-6521, 2006.

156. Richardson DR, Vitolo LMW, Hefter GT, May PM, Clare BW, Webb J, Wilairat P. Iron chelators of the pyridoxal isonicotinoyl hydrazone class Part I. Ionisation 
characteristics of the ligands and their relevance to biological properties. Inorganica Chimica Acta 170: 165-170, 1990.

157.

158. Sahni S, Bae DH, Lane DJ, Kovacevic Z, Kalinowski DS, Jansson PJ, Richardson DR. The metastasis suppressor, N-myc downstream-regulated gene 1 (NDRG1), inhibits stress-induced autophagy in cancer cells. J Biol Chem 289: 9692-709, 2014.

159. Salim KY, Maleki Vareki S, Danter WR, Koropatnick J. COTI-2, a novel small molecule that is active against multiple human cancer cell lines in vitro and in vivo. Oncotarget 7: 41363-41379, 2016.

160. Sarkadi B, Homolya L, Szakacs G, Varadi A. Human multidrug resistance ABCB and ABCG transporters: participation in a chemoimmunity defense system. Physiol Rev 86: 1179-236, 2006.

161. Saryan LA, Mailer K, Krishnamurti C, Antholine W, Petering DH. Interaction of 2formylpyridine thiosemicarbazonato copper(II) with Ehrlich ascites tumor cells. Biochem Pharmacol 30: 1595-604, 1981.

162. Scariot DB, Britta EA, Moreira AL, Falzirolli H, Silva CC, Ueda-Nakamura T, Dias-Filho BP, Nakamura CV. Induction of Early Autophagic Process on Leishmania amazonensis by Synergistic Effect of Miltefosine and Innovative Semi-synthetic Thiosemicarbazone. Front Microbiol 8: 255, 2017.

163. Schelman WR, Morgan-Meadows S, Marnocha R, Lee F, Eickhoff J, Huang W, Pomplun M, Jiang Z, Alberti D, Kolesar JM, Ivy P, Wilding G, Traynor AM. A phase I study of Triapine in combination with doxorubicin in patients with advanced solid tumors. Cancer Chemother Pharmacol 63: 1147-56, 2009.

164. Seebacher NA, Lane DJ, Jansson PJ, Richardson DR. Glucose Modulation Induces Lysosome Formation and Increases Lysosomotropic Drug Sequestration via the PGlycoprotein Drug Transporter. J Biol Chem 291: 3796-820, 2016.

165. Seebacher NA, Richardson DR, Jansson PJ. Glucose modulation induces reactive oxygen species and increases P-glycoprotein-mediated multidrug resistance to chemotherapeutics. Br J Pharmacol 172: 2557-72, 2015. 
166. Sengupta R, Holmgren A. Thioredoxin and glutaredoxin-mediated redox regulation of ribonucleotide reductase. World J Biol Chem 5: 68-74, 2014.

167. Shao J, Zhou B, Di Bilio AJ, Zhu L, Wang T, Qi C, Shih J, Yen Y. A Ferrous-Triapine complex mediates formation of reactive oxygen species that inactivate human ribonucleotide reductase. Mol Cancer Ther 5: 586-92, 2006.

168. Shenberger $Y$, Shimshi A, Ruthstein S. EPR spectroscopy shows that the blood carrier protein, human serum albumin, closely interacts with the $\mathrm{N}$-terminal domain of the copper transporter, Ctr1. J Phys Chem B 119: 4824-30, 2015.

169. Shoemaker RH. The NCI60 human tumour cell line anticancer drug screen. Nat Rev Cancer 6: 813-23, 2006.

170. Sinniah SK, Tan KW, Ng SW, Sim KS. Thiosemicarbazone derivative induces in vitro apoptosis in metastatic PC-3 cells via activation of mitochondrial pathway. Anticancer Agents Med Chem, 2016.

171. Soares Moretti Al, Martins Laurindo FR. Protein disulfide isomerases: Redox connections in and out of the endoplasmic reticulum. Arch Biochem Biophys 617: 106-119, 2017.

172. Spasojević I, Armstrong SK, Brickman TJ, Crumbliss AL. Electrochemical behavior of the Fe (III) complexes of the cyclic hydroxamate siderophores alcaligin and desferrioxamine E. Inorganic chemistry 38: 449-454, 1999.

173. Sreekanth A, Fun H-K, Kurup MP. Structural and spectral studies of an iron (III) complex [Fe (Pranthas) 2] $[\mathrm{FeCl} 4]$ derived from 2-acetylpyridine- $\mathrm{N}$ (4), $\mathrm{N}$ (4)(butane-1, 4-diyl) thiosemicarbazone (HPranthas). Journal of molecular structure 737: 61-67, 2005.

174. Stacy AE, Palanimuthu D, Bernhardt PV, Kalinowski DS, Jansson PJ, Richardson DR. Zinc(II)-Thiosemicarbazone Complexes Are Localized to the Lysosomal Compartment Where They Transmetallate with Copper Ions to Induce Cytotoxicity. J Med Chem 59: 4965-84, 2016.

175. Szakacs G, Annereau JP, Lababidi S, Shankavaram U, Arciello A, Bussey KJ, Reinhold W, Guo Y, Kruh GD, Reimers M, Weinstein JN, Gottesman MM. Predicting drug sensitivity and resistance: profiling $A B C$ transporter genes in cancer cells. Cancer Cell 6: 129-37, 2004. 
176. Szakacs G, Hall MD, Gottesman MM, Boumendjel A, Kachadourian R, Day BJ, Baubichon-Cortay H, Di Pietro A. Targeting the Achilles heel of multidrug-resistant cancer by exploiting the fitness cost of resistance. Chem Rev 114: 5753-74, 2014.

177. Szakacs G, Paterson JK, Ludwig JA, Booth-Genthe C, Gottesman MM. Targeting multidrug resistance in cancer. Nat Rev Drug Discov 5: 219-34, 2006.

178. Thelander L, Graslund A. Mechanism of inhibition of mammalian ribonucleotide reductase by the iron chelate of 1-formylisoquinoline thiosemicarbazone. Destruction of the tyrosine free radical of the enzyme in an oxygen-requiring reaction. J Biol Chem 258: 4063-6, 1983.

179. Traynor AM, Lee JW, Bayer GK, Tate JM, Thomas SP, Mazurczak M, Graham DL, Kolesar JM, Schiller JH. A phase II trial of triapine (NSC\# 663249) and gemcitabine as second line treatment of advanced non-small cell lung cancer: Eastern Cooperative Oncology Group Study 1503. Invest New Drugs 28: 91-7, 2010.

180. Trondl R, Flocke LS, Kowol CR, Heffeter P, Jungwirth U, Mair GE, Steinborn R, Enyedy EA, Jakupec MA, Berger W, Keppler BK. Triapine and a more potent dimethyl derivative induce endoplasmic reticulum stress in cancer cells. Mol Pharmacol 85: 451-9, 2014.

181. Tsimberidou AM, Alvarado Y, Giles FJ. Evolving role of ribonucleoside reductase inhibitors in hematologic malignancies. Expert Rev Anticancer Ther 2: 437-48, 2002.

182. Turk D, Hall MD, Chu BF, Ludwig JA, Fales HM, Gottesman MM, Szakacs G. Identification of compounds selectively killing multidrug-resistant cancer cells. Cancer Res 69: 8293-301, 2009.

183. Umbreit J. Methemoglobin--it's not just blue: a concise review. Am J Hematol 82: 134-44, 2007.

184. van Zwieten R, Verhoeven AJ, Roos D. Inborn defects in the antioxidant systems of human red blood cells. Free Radic Biol Med 67: 377-86, 2014.

185. Vitolo LMW, Hefter GT, Clare BW, Webb J. Iron chelators of the pyridoxal isonicotinoyl hydrazone class Part II. Formation constants with iron (III) and iron (II). Inorganica chimica acta 170: 171-176, 1990.

186. Wadler S, Makower D, Clairmont C, Lambert P, Fehn K, Sznol M. Phase I and pharmacokinetic study of the ribonucleotide reductase inhibitor, 3-aminopyridine- 
2-carboxaldehyde thiosemicarbazone, administered by 96-hour intravenous continuous infusion. J Clin Oncol 22: 1553-63, 2004.

187. Wang J, Yin D, Xie C, Zheng T, Liang Y, Hong X, Lu Z, Song X, Song R, Yang H, Sun B, Bhatta N, Meng X, Pan S, Jiang H, Liu L. The iron chelator Dp44mT inhibits hepatocellular carcinoma metastasis via N-Myc downstream-regulated gene 2 (NDRG2)/gp130/STAT3 pathway. Oncotarget 5: 8478-91, 2014.

188. Wangpu X, Lu J, Xi R, Yue F, Sahni S, Park KC, Menezes S, Huang ML, Zheng M, Kovacevic Z, Richardson DR. Targeting the Metastasis Suppressor, N-Myc Downstream Regulated Gene-1, with Novel Di-2-Pyridylketone Thiosemicarbazones: Suppression of Tumor Cell Migration and Cell-Collagen Adhesion by Inhibiting Focal Adhesion Kinase/Paxillin Signaling. Mol Pharmacol 89: 521-40, 2016.

189. Whitnall M, Howard J, Ponka P, Richardson DR. A class of iron chelators with a wide spectrum of potent antitumor activity that overcomes resistance to chemotherapeutics. Proc Natl Acad Sci U S A 103: 14901-6, 2006.

190. Wicki A, Mandala M, Massi D, Taverna D, Tang H, Hemmings BA, Xue G. Acquired Resistance to Clinical Cancer Therapy: A Twist in Physiological Signaling. Physiol Rev 96: 805-29, 2016.

191. Wu CP, Shukla S, Calcagno AM, Hall MD, Gottesman MM, Ambudkar SV. Evidence for dual mode of action of a thiosemicarbazone, NSC73306: a potent substrate of the multidrug resistance linked ABCG2 transporter. Mol Cancer Ther 6: 3287-96, 2007.

192. Xi R, Pun IH, Menezes SV, Fouani L, Kalinowski DS, Huang ML, Zhang X, Richardson DR, Kovacevic Z. Novel Thiosemicarbazones Inhibit Lysine-Rich Carcinoembryonic Antigen-Related Cell Adhesion Molecule 1 (CEACAM1) Coisolated (LYRIC) and the LYRIC-Induced Epithelial-Mesenchymal Transition via Upregulation of N-Myc Downstream-Regulated Gene 1 (NDRG1). Mol Pharmacol 91: 499-517, 2017.

193. Xu Z, Liu Y, Zhou S, Fu Y, Li C. Analysis of the Interaction of Dp44mT with Human Serum Albumin and Calf Thymus DNA Using Molecular Docking and Spectroscopic Techniques. Int J Mol Sci 17, 2016.

194. Yamagishi T, Sahni S, Sharp DM, Arvind A, Jansson PJ, Richardson DR. P-glycoprotein mediates drug resistance via a novel mechanism involving lysosomal sequestration. 
J Biol Chem 288: 31761-71, 2013.

195. Yu N, Zhu H, Yang Y, Tao Y, Tan F, Pei Q, Zhou Y, Song X, Tan Q, Pei H. Combination of $\mathrm{Fe} / \mathrm{Cu}$-chelators and docosahexaenoic acid: an exploration for the treatment of colorectal cancer. Oncotarget 8: 51478-51491, 2017.

196. Yu X, Vazquez A, Levine AJ, Carpizo DR. Allele-specific p53 mutant reactivation. Cancer Cell 21: 614-25, 2012.

197. Yu Y, Kalinowski DS, Kovacevic Z, Siafakas AR, Jansson PJ, Stefani C, Lovejoy DB, Sharpe PC, Bernhardt PV, Richardson DR. Thiosemicarbazones from the old to new: iron chelators that are more than just ribonucleotide reductase inhibitors. J Med Chem 52: 5271-94, 2009.

198. Yu Y, Suryo Rahmanto Y, Hawkins CL, Richardson DR. The potent and novel thiosemicarbazone chelators di-2-pyridylketone-4,4-dimethyl-3-thiosemicarbazone and 2-benzoylpyridine-4,4-dimethyl-3-thiosemicarbazone affect crucial thiol systems required for ribonucleotide reductase activity. Mol Pharmacol 79: 921-31, 2011.

199. Yu Y, Wong J, Lovejoy DB, Kalinowski DS, Richardson DR. Chelators at the cancer coalface: desferrioxamine to Triapine and beyond. Clin Cancer Res 12: 6876-83, 2006.

200. Yuan J, Lovejoy DB, Richardson DR. Novel di-2-pyridyl-derived iron chelators with marked and selective antitumor activity: in vitro and in vivo assessment. Blood 104: 1450-8, 2004.

201. Zhang C. Essential functions of iron-requiring proteins in DNA replication, repair and cell cycle control. Protein Cell 5: 750-60, 2014.

202. Zhu L, Zhou B, Chen X, Jiang H, Shao J, Yen Y. Inhibitory mechanisms of heterocyclic carboxaldehyde thiosemicabazones for two forms of human ribonucleotide reductase. Biochem Pharmacol 78: 1178-85, 2009. 


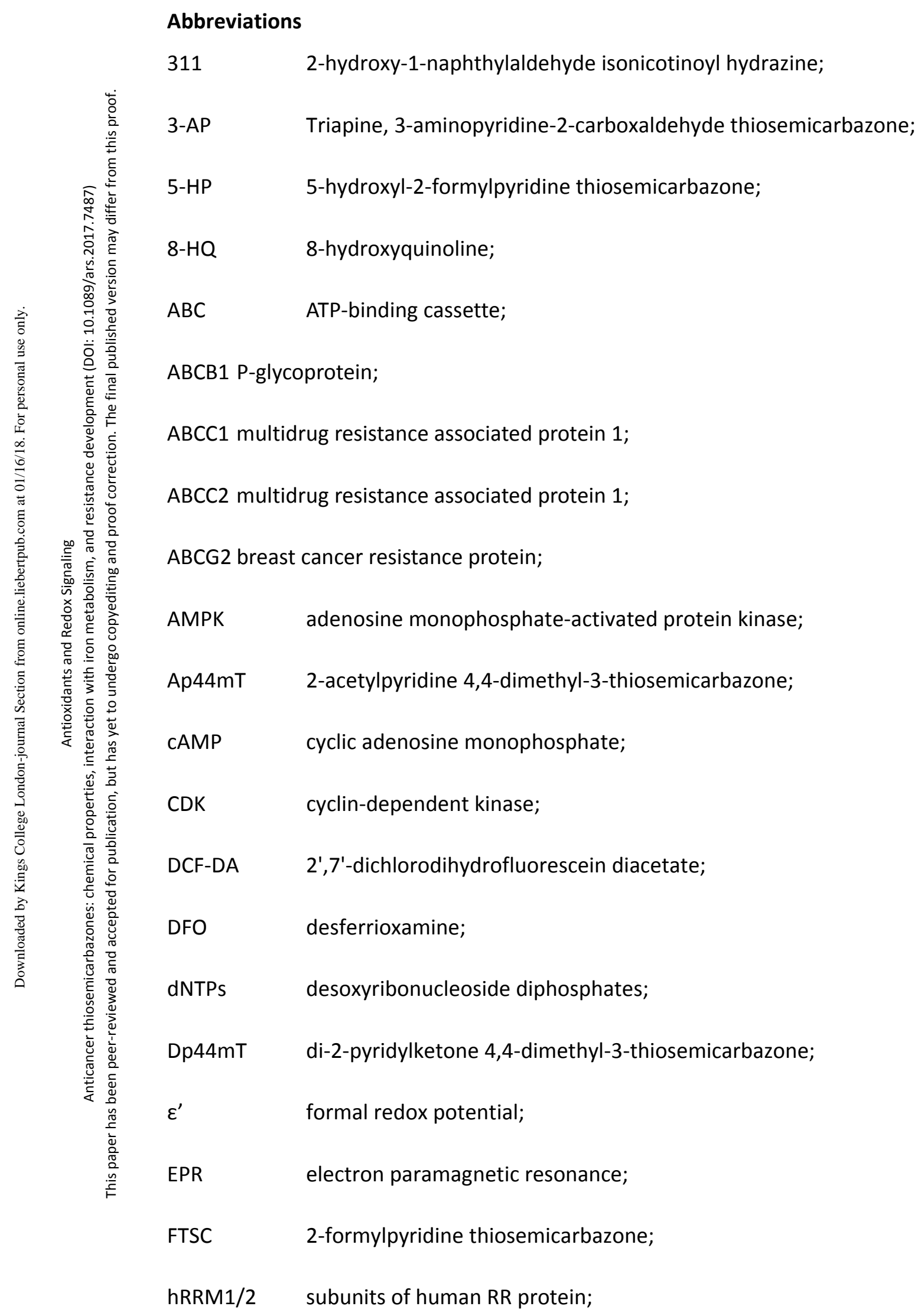


MAIQ 4-methyl-5-amino-1-formylisoquinoline thiosemicarbazone;

MDR multidrug resistance; 
Table 1. Cumulative stability constants ( $\log \beta)$ of iron(III) and iron(II) complexes of DFO and selected thiosemicarbazones.

\begin{tabular}{cccccc}
\hline logb & DFO & Triapine & FTSC & Dp44mT & STSC \\
\hline $\mathrm{Fe}(\mathrm{III}) \mathrm{L}$ & $30.4^{\mathrm{a}}$ & n. r. & n. r. & n. r. & n. r. \\
$\mathrm{Fe}(\mathrm{II}) \mathrm{L}$ & $10^{\mathrm{b}}$ & n. r. & n.r. & n. r. & n. r. \\
\hline $\mathrm{Fe}(\mathrm{III}) \mathrm{L}_{2}$ & n. r. & $26.25^{\mathrm{c}}$ & $25.36^{\mathrm{c}}$ & $23.6^{\mathrm{d}}$ & $34.02^{\mathrm{e}}$ \\
\hline $\mathrm{Fe}(\mathrm{II}) \mathrm{L}_{2}$ & n. r. & $22.55^{\mathrm{c}}$ & $22.31^{\mathrm{c}}$ & $21.2^{\mathrm{d}}$ & $24.73^{\mathrm{e}}$
\end{tabular}

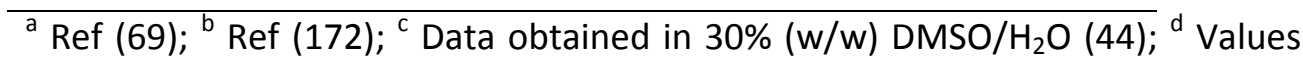
estimated from the conditional constants obtained at $\mathrm{pH}$ 5: $\mathrm{Fe}(\mathrm{III}) \mathrm{L}_{2}: 12.67$ and $\mathrm{Fe}(\mathrm{II}) \mathrm{L}_{2}: 10.25$ (52); ${ }^{\mathrm{e}}$ Data obtained in 30\% (w/w) DMSO/ $\mathrm{H}_{2} \mathrm{O}(45)$. n. r. = not relevant for the given ligand system. 
Table 2. Physico-chemical properties of selected iron(III) complexes formed with ligands containing different donor atoms

\begin{tabular}{|c|c|c|c|}
\hline Ligand & coordination mode & $p M^{a}$ & $\varepsilon^{\prime}(m V)$ vs. NHE \\
\hline Deferiprone & $3 \times\left(0,0^{-}\right)$ & $20.5(76) ; 19.4(77)$ & $-620(123)$ \\
\hline Deferasirox & $2 \times\left(\mathrm{O}^{-}, \mathrm{N}, \mathrm{O}^{-}\right)$ & $22.5(75)$ & $-600(76)$ \\
\hline DFO & $\left(0,0^{-}, 0,0^{-}, 0,0^{-}\right)$ & $26.6(172)$ & $-482(172)$ \\
\hline $8-\mathrm{HQ}$ & $3 \times\left(\mathrm{O}^{-}, \mathrm{N}\right)$ & $20.6(76)$ & $-150(76)$ \\
\hline Triapine & $2 \times\left(N, N, S^{-}\right)$ & $15.7(44)$ & $+70(44),+40(150)$ \\
\hline $\mathrm{DpC}$ & $2 \times\left(N, N, S^{-}\right)$ & not available & +94 (150) \\
\hline Dp44mT & $2 \times\left(\mathrm{N}, \mathrm{N}, \mathrm{S}^{-}\right)$ & $\sim 14(52)^{b}$ & +113 (150), +166 (155) \\
\hline $\mathrm{PIH}$ & $2 \times\left(\mathrm{O}^{-}, \mathrm{N}, \mathrm{O}^{-}\right)$ & $22.9(156)(185)^{c}$ & $+130(75)$ \\
\hline Phen & $3 \times(N, N)$ & unstable & $+1140(113)$ \\
\hline Transferrin & $\begin{array}{l}\left(\mathrm{COO}^{-}, \mathrm{O}^{-}, \mathrm{N}, \mathrm{O}^{-}\right. \\
\left., \mathrm{CO}_{3}{ }^{2-}\right)\end{array}$ & $20.3(130)$ & not available \\
\hline \multicolumn{4}{|c|}{$\begin{array}{l}\text { a pM values }(\mathrm{pM}=-\log [\mathrm{Fe}(\mathrm{III})] \text { at } \mathrm{cFe}(\mathrm{III})=1 \mu \mathrm{M} ; \mathrm{cL}=10 \mu \mathrm{M} ; \mathrm{pH}=7.4) \text { and formal }\left(\varepsilon^{\prime}\right) \\
\text { potentials vs. NHE of the iron(III)/iron(II) complexes }(\mathrm{pH}=7.4) .{ }^{\mathrm{b}} \mathrm{pM} \text { is estimated on the } \\
\text { basis of the conditional constants reported at } \mathrm{pH} 5 \text { in reference }(52) \text { and transferred to } \mathrm{pH}\end{array}$} \\
\hline
\end{tabular}


Table 3. Overview on biological thiosemicarbazone targets described.

\begin{tabular}{|c|c|c|}
\hline Target & Drug & Level of evidence (used method) \\
\hline \multirow[t]{2}{*}{ Hemoglobin } & Triapine & In humans (methemoglobinemia) $(94,107)$ \\
\hline & Dp44mT & $\begin{array}{l}\text { In mice and isolated human red blood cells (methemoglobin } \\
\text { formation) (150) }\end{array}$ \\
\hline \multirow[t]{6}{*}{ RR } & Triapine & In humans (depletion of dNTP pools in leukemia cells) $(56,109)$ \\
\hline & & $\begin{array}{l}\text { Cell culture (whole cell EPR, inhibition of dCTP production) } \\
(6,99)\end{array}$ \\
\hline & & Cell-free enzyme inhibition (EPR) $(167,202)$ \\
\hline & Dp44mT, & Cell culture (whole cell EPR) (198) \\
\hline & Dp4eT & \\
\hline & IQ-1 & Cell-free enzyme inhibition (EPR) (178) \\
\hline \multirow[t]{3}{*}{ DNA } & Triapine & Cell culture (H2AX phosphorylation) $(83,108)$ \\
\hline & & $\begin{array}{l}\text { In mice (immunofluorescence stain, } \mathrm{H} 2 \mathrm{AX} \text { phosphorylation in } \\
\text { subcutaneous tumors, unpublished results) }\end{array}$ \\
\hline & Dp44mT & Cell culture (H2AX phosphorylation) $(83,151)$ \\
\hline \multirow[t]{2}{*}{ STAT3 } & $\begin{array}{l}\text { DpC, } \\
\text { Dp44mT }\end{array}$ & $\begin{array}{l}\text { In mice (immunofluorescence stain of subcutaneous tumors) } \\
\text { (119) }\end{array}$ \\
\hline & & Cell culture (Western blot, DNA-binding activity) $(119,187)$ \\
\hline \multirow[t]{3}{*}{ NDRG1/2/3 } & $\mathrm{Dp} 44 \mathrm{mT}$ & $\begin{array}{l}\text { In mice (immunofluorescence stain of subcutaneous tumors) } \\
\text { (110) }\end{array}$ \\
\hline & & Cell culture (Western blot) $(110,120,187)$ \\
\hline & $\mathrm{DpC}$ & Cell culture (Western blot) (97) \\
\hline \multirow[t]{2}{*}{ Cyclin A } & Triapine & Cell culture (Western blot) (23) \\
\hline & TSC24 & Cell culture (Western blot) (7) \\
\hline \multirow[t]{3}{*}{ Cyclin D } & Triapine & Cell culture (Western blot) (23) \\
\hline & Dp44mT & Cell culture (Western blot) $(110,111)$ \\
\hline & $\mathrm{DpC}$ & Cell culture (Western blot) (97) \\
\hline \multirow[t]{2}{*}{ CDK2/4 } & Triapine & Cell culture (Western blot) (23) \\
\hline & Bp4eT, & Cell culture (CDK2 activity by immunoprecipitation) (35) \\
\hline
\end{tabular}


Page 56 of 63

Dp44mT

\begin{tabular}{|c|c|c|c|}
\hline & PDE4D & Triapine & Cell culture (loss in resistant cell lines) (126) \\
\hline \multirow{9}{*}{ 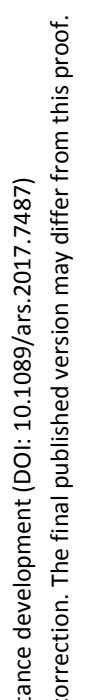 } & P53 & NSC319725, & Cell culture (restoring p53-wt confirmation) (196) \\
\hline & & NSC319726, & \\
\hline & & NSC328784 & \\
\hline & P21 & $\mathrm{DpC}$ & Cell culture (Western blot) $(97,131)$ \\
\hline & & TSC24 & Cell culture (Western blot) (7) \\
\hline & Trx2 & Triapine & Cell culture (Western blot) (134) \\
\hline & Prx3 & Triapine, & Cell culture (Western blot) (133) \\
\hline & & Dp44mT & \\
\hline & AMPK & Dp44mT & Cell culture (Western blot) (104) \\
\hline
\end{tabular}




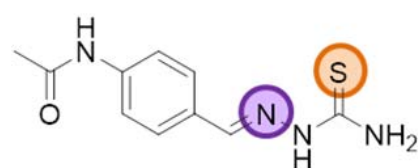

Thioacetazone

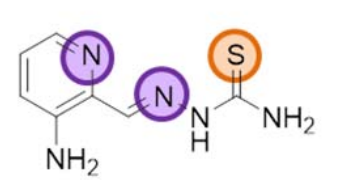

Triapine

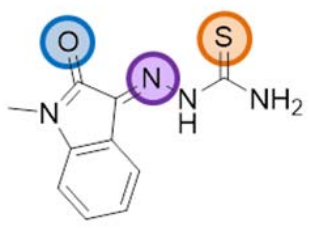

Methisazone

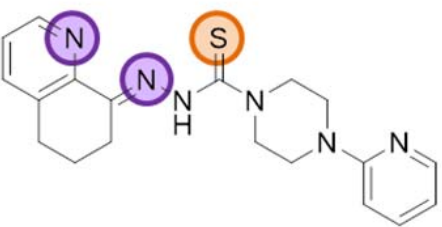

COTI-2

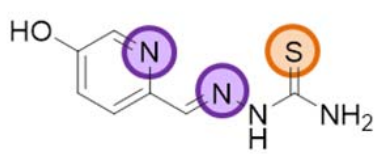

$5-\mathrm{HP}$

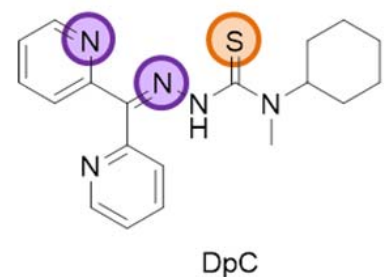

Figure 1: Chemical structures of clinically investigated or approved thiosemicarbazones with highlighted donor atoms. (To see this illustration in color, the reader is referred to the online version of this article at www.liebertpub.com/ars). 


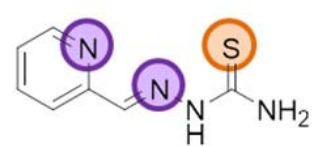

FTSC

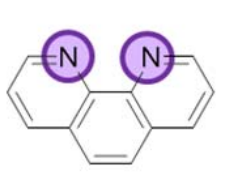

1,10-Phenanthroline
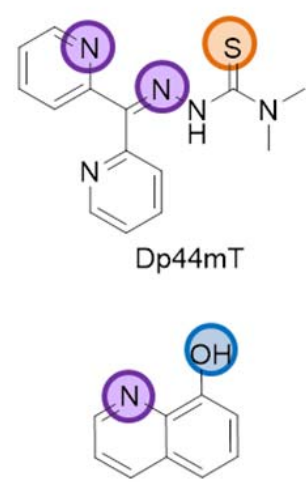

8-Hydroxyquinoline
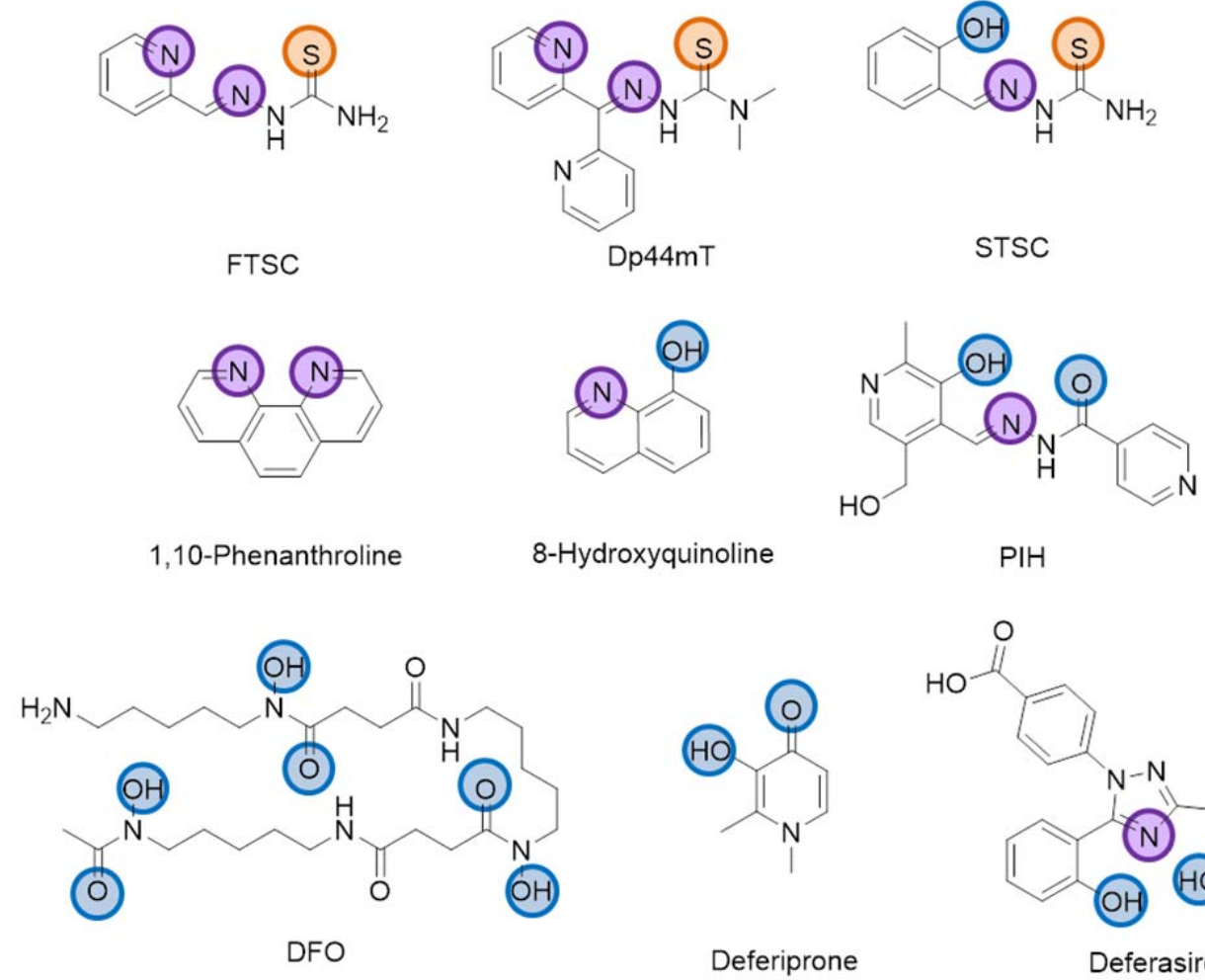

$\mathrm{PIH}$

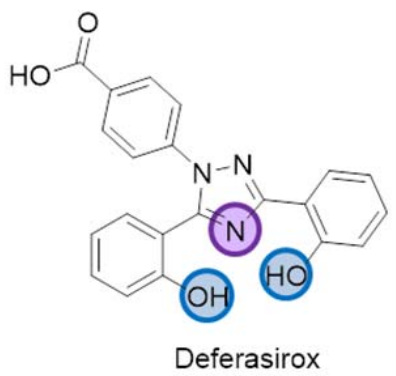

Figure 2: Chemical structures of the $\alpha-N$-heterocyclic thiosemicarbazones FTSC and Dp44mT with N,N,S donor sets, STSC with $\mathrm{O}, \mathrm{N}, \mathrm{S}$ donor atoms, the iron chelators 1,10phenanthroline (phen), 8-hydroxyquinoline (8-HQ) and pyridoxal isonicotinoyl hydrazine (PIH) as well as the clinically approved iron(III) chelators desferrioxamine (DFO), deferiprone and deferasirox. (To see this illustration in color, the reader is referred to the online version of this article at www.liebertpub.com/ars). 


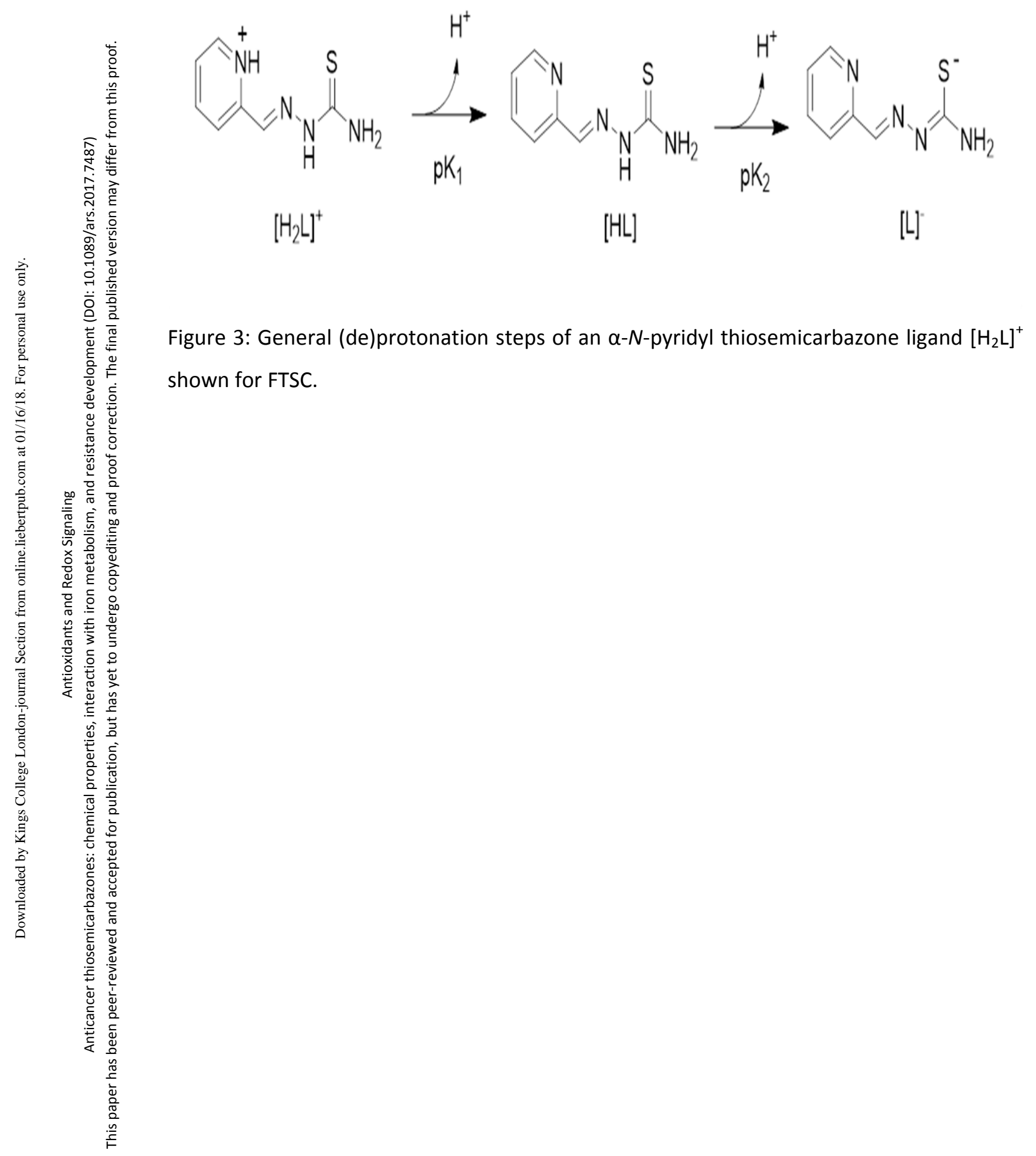


60

Fractions of formed

Fe(II) complexes

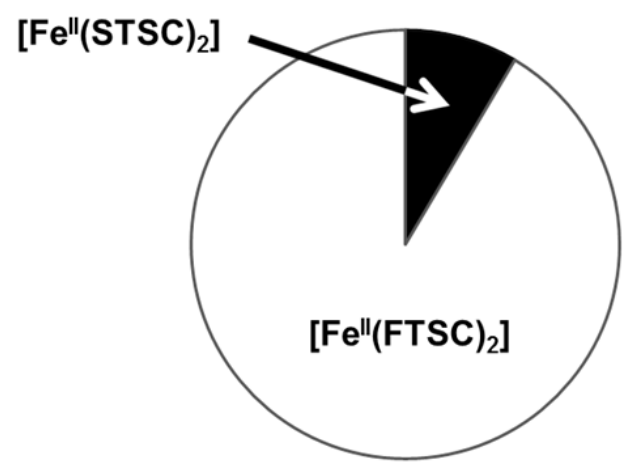

Fractions of formed $\mathrm{Fe}$ (III) complexes

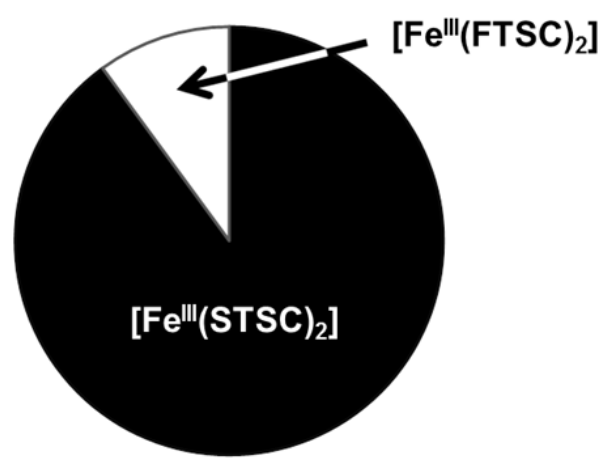

Figure 4. Distribution of iron(II) and iron(III) between two different types of thiosemicarbazone complexes in a hypothetic metal/FTSC/STSC (1:2:2) ternary system at $\mathrm{pH} 7.4\left(\mathrm{C}_{\mathrm{Fe}}=1 \mathrm{mM}\right)$ calculated based on the stability constants $(43,44)$. The STSC ligands with the harder $(\mathrm{O}, \mathrm{N}, \mathrm{S}$,$) donor set have a much higher affinity for \mathrm{Fe}(\mathrm{III})$ ions, whereas the $(\mathrm{N}, \mathrm{N}, \mathrm{S})$ donor set of FTSC prefers iron(II) ions. 


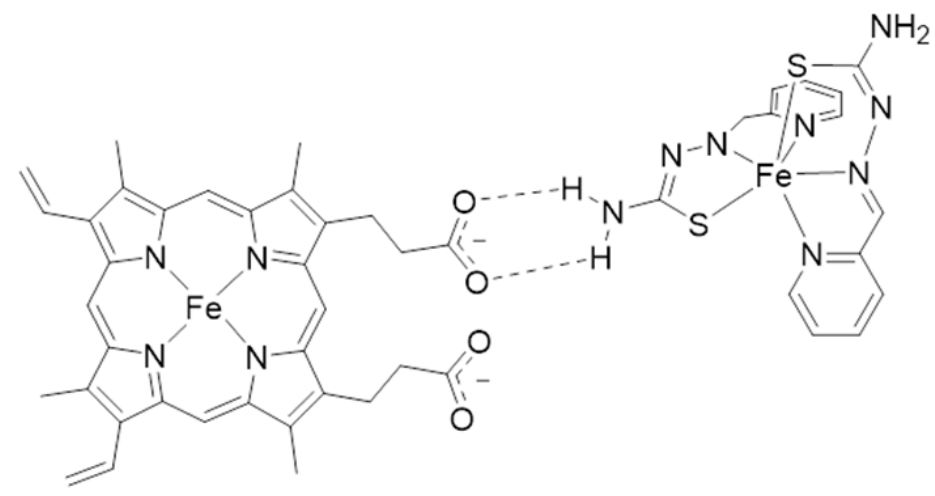

Figure 5. Possible interaction of the iron complex of a terminally unsubstituted thiosemicarbazone and the porphyrin system of hemoglobin (drawn according to reference (11)). 


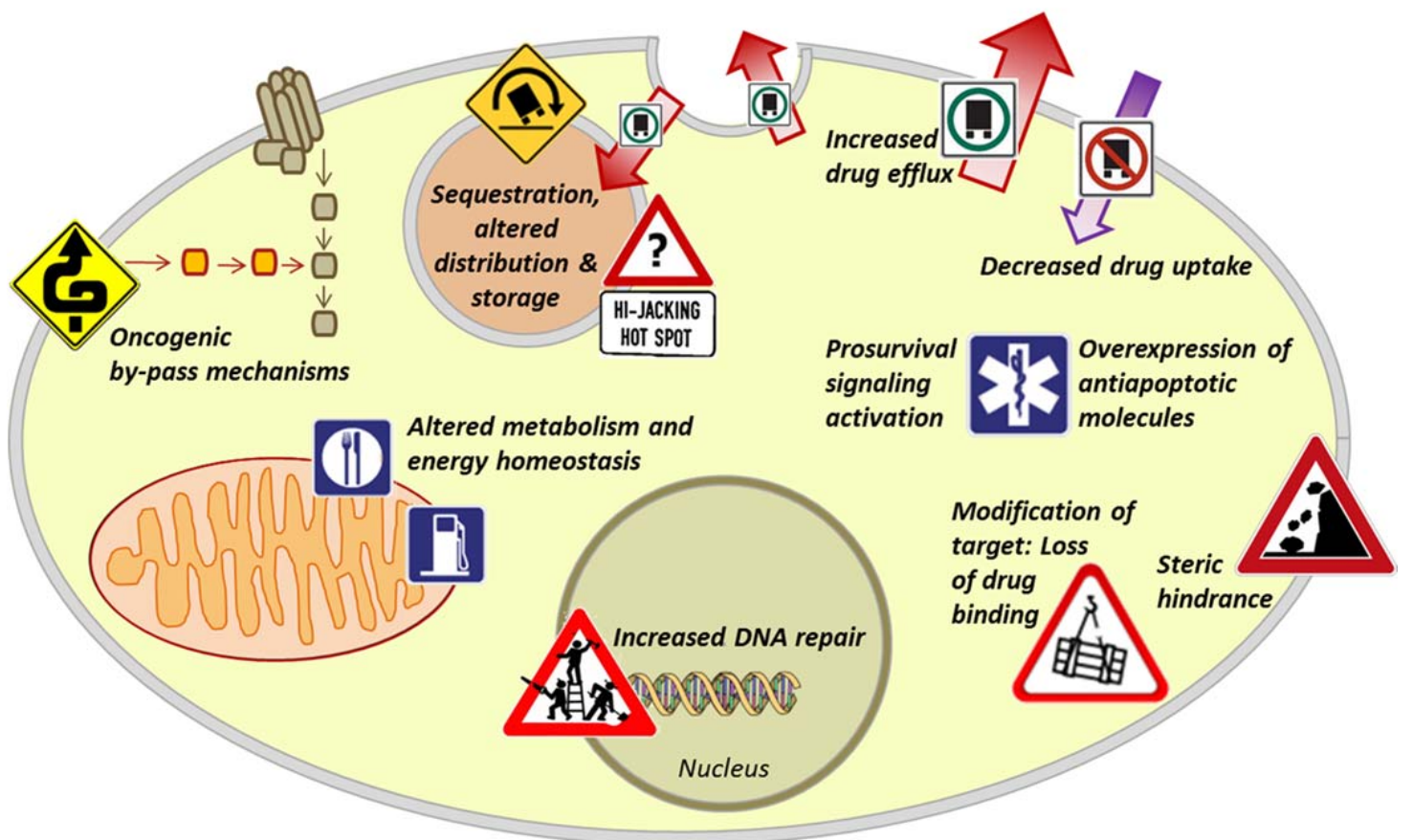

Figure 6. Cellular mechanisms of resistance. The development of MDR is a multifactorial process, and the MDR phenotype implies a number of cellular changes. Resistance can emerge as a result of genetic changes. Here, targets can be overexpressed or structurally modified in a manner that drug binding is reduced, or sterically hindered. Adaption can also rely on increased repair of the damage (e.g. DNA adducts). Especially in case of targeted drugs, alternative signaling pathways can be modified, in order to overcome the dependence on the drug target. Altered cellular metabolism can lead to the inactivation or decreased activation of the cytotoxic agent, accompanied by changes in metabolic enzymes, as well as by changes in cellular energy metabolism, metal- and redox homeostasis. Furthermore, the cellular response to drugs can also be altered by lowering intracellular drug concentrations as a result of the reduced uptake or the enhanced efflux of compounds. Usually, efflux is based on energy-dependent transport mediated by ATPbinding-cassette $(A B C)$ proteins, such as $A B C B 1$. In addition, altered intracellular drug distribution has been frequently described for drug-resistant cells. (To see this illustration in color, the reader is referred to the online version of this article at www.liebertpub.com/ars). 
Annulated aromatic rings not allowed $\checkmark$

Figure 7: SAR / pharmacophore model of isatin- $\beta$-thiosemicarbazone, based on $(62,63,167)$. The thiosemicarbazone scaffold and a bulky or aromatic moiety at N4 are required for MDR-selective toxicity. Substitutions of the aromatic moiety at position 4' were found to be optimal, while ortho $\left(2^{\prime}\right)$ and meta $\left(3^{\prime}\right)$ substitutions were not beneficial (167). The isatin moiety - or at least the lactam - seems to be necessary for selective activity. An extension of the aromatic ring system disrupts activity, while substitution at the 5th position might be tolerated in case of halogens or a nitro-group, but not in case of a sulfonate, which might be explained by a reduced cell permeability of the resulting negatively charged molecule (63). 